\title{
Iron isotope fractionation in subduction-related high-pressure metabasites (Ile de Groix, France)
}

\author{
Afifé El Korh ${ }^{1,2} \cdot$ Béatrice Luais $^{1} \cdot$ Etienne Deloule $^{1} \cdot$ Damien Cividini $^{1}$
}

\begin{abstract}
Characterisation of mass transfer during subduction is fundamental to understand the origin of compositional heterogeneities in the upper mantle. Fe isotopes were measured in high-pressure/low-temperature metabasites (blueschists, eclogites and retrograde greenschists) from the Ile de Groix (France), a Variscan high-pressure terrane, to determine if the subducted oceanic crust contributes to mantle $\mathrm{Fe}$ isotope heterogeneities. The metabasites have $\delta^{56} \mathrm{Fe}$ values of +0.16 to $+0.33 \%$, which are heavier than typical values of MORB and OIB, indicating that their basaltic protolith derives from a heavy-Fe mantle source. The $\delta^{56} \mathrm{Fe}$ correlates well with $\mathrm{Y} / \mathrm{Nb}$ and $(\mathrm{La} / \mathrm{Sm})_{\mathrm{PM}}$ ratios, which commonly fractionate during magmatic processes, highlighting variations in the magmatic protolith composition. In addition, the shift of $\delta^{56} \mathrm{Fe}$ by +0.06 to $0.10 \%$ o compared to basalts may reflect hydrothermal alteration prior to subduction. The $\delta^{56} \mathrm{Fe}$ decrease from blueschists $(+0.19 \pm 0.03$ to $+0.33 \pm 0.01 \%$ o $)$ to eclogites $(+0.16 \pm 0.02$ to $+0.18 \pm 0.03 \%$ o $)$ reflects small variations in the protolith composition, rather than $\mathrm{Fe}$ fractionation
\end{abstract}

Electronic supplementary material

Afifé El Korh

afife.elkorh@unifr.ch

1 Centre de Recherches Pétrographiques et Géochimiques (CRPG), UMR 7358 CNRS-Université de Lorraine, 15 rue Notre Dame des Pauvres, BP 20, 54501 Vandœuvre-Lès-Nancy Cedex, France

2 Unit of Earth Sciences, Department of Geosciences, University of Fribourg, Chemin du Musée 6, 1700 Fribourg, Switzerland during metamorphism: newly-formed Fe-rich minerals allowed preserving bulk rock Fe compositions during metamorphic reactions and hampered any Fe isotope fractionation. Greenschists have $\delta^{56} \mathrm{Fe}$ values $(+0.17 \pm 0.01$ to $+0.27 \pm 0.02 \%$ ) similar to high-pressure rocks. Hence, metasomatism related to fluids derived from the subducted hydrothermally altered metabasites might only have a limited effect on mantle $\mathrm{Fe}$ isotope composition under subsolidus conditions, owing to the large stability of Fe-rich minerals and low mobility of Fe. Subsequent melting of the heavy-Fe metabasites at deeper levels is expected to generate mantle $\mathrm{Fe}$ isotope heterogeneities.

Keywords Fe isotopes $\cdot$ Metabasites $\cdot$ Subduction $\cdot$ HP-LT metamorphism · Blueschists · Eclogites · Greenschists · Basaltic protoliths

\section{Introduction}

High-pressure/low-temperature (HP-LT) rocks are remnants of ancient subduction zones. They provide information on geochemical processes and deep fluid-rock interactions occurring at present-day active convergent margins. Fluid infiltration during high- and lowtemperature hydrothermal alteration of the oceanic crust at mid-ocean ridges and on the seafloor is responsible for the hydration of basic rocks and serpentinisation of the lithospheric mantle. During subduction, the hydrothermally altered oceanic crust dehydrates continuously and releases large amounts of $\mathrm{H}_{2} \mathrm{O}$ at a relatively shallow level in the subduction zone (50-80 km) (Schmidt and Poli 1998; Rüpke et al. 2004). Deserpentinisation of the lithospheric mantle occurs at deeper levels (100-200 km), where fluids are expected to be the source of arc melting (Ulmer and 
Trommsdorff 1995; Rüpke et al. 2004). Fluid- and meltmediated mass transfer from the slab to the overlying mantle wedge during devolatilisation reactions, triggers mantle metasomatism (e.g. Schmidt and Poli 1998; Downes 2001; Kessel et al. 2005).

Currently, fluid-induced oxidation of the mantle wedge during subduction is a matter of debate (e.g. Evans 2012; and references therein). Dehydration-redox reactions happening in the subducting slab are responsible for a transfer of redox-sensitive $(\mathrm{Fe})$ or volatile elements (C, S, F, Cl) from subducted sediments, altered oceanic crust and serpentinised lithospheric mantle to the mantle wedge (e.g. Malaspina et al. 2010; Evans 2012; Galvez et al. 2013; Debret et al. 2016). These processes in turn control the redox state of arc magmas, which are shown to be more oxidised $\left(\mathrm{Fe}^{3+} / \Sigma \mathrm{Fe}=0.3\right)$ than mid-ocean ridge basalts $(\mathrm{MORB})\left(\mathrm{Fe}^{3+} / \Sigma \mathrm{Fe}=0.07-0.16\right.$; Christie et al. 1986; Bezos and Humler 2005; Kelley and Cottrell 2009; Cottrell and Kelley 2011), and have long-term (>1 Ga) consequences for the bulk mantle (Evans 2012). Hypersaline brines, supercritical fluids, silicate-rich C-bearing fluids, silicate melts or sulphate-bearing fluids derived from the oceanic lithosphere are recognised as effective metasomatic oxidising agents in the lithospheric mantle (Kelley and Cottrell 2009; Malaspina et al. 2010; Debret et al. 2016). The prograde transition from lizardite to antigorite results in a decrease of the serpentine $\mathrm{Fe}^{3+}$ / $\Sigma \mathrm{Fe}$ ratio and magnetite modal percentage under eclogite facies conditions (Debret et al. 2014). Fe mass transfer accompanying the release of oxidised fluids (e.g. $\mathrm{SO}_{X}$, $\mathrm{H}_{2} \mathrm{O}, \mathrm{CO}_{2}$ ) leads to $\mathrm{Fe}$ reduction in serpentinites (Debret et al. 2014).

Iron isotopes $\left({ }^{54} \mathrm{Fe},{ }^{56} \mathrm{Fe},{ }^{57} \mathrm{Fe}\right.$ and $\left.{ }^{58} \mathrm{Fe}\right)$ may be a tool with which these mass transfer processes can be tracked, because their distribution is strongly sensitive to changes in redox conditions (e.g. Williams et al. 2005, 2009; Dauphas et al. 2009; Sossi et al. 2012, 2016; Teng et al. 2013). Fe isotopes may fractionate significantly at high-temperature $\left(>700{ }^{\circ} \mathrm{C}\right)$ in mantle-derived rocks and minerals (deviation of the ${ }^{x} \mathrm{Fe} /{ }^{54} \mathrm{Fe}$ ratio is noted as $\delta^{x} \mathrm{Fe}=\left[\left({ }^{x} \mathrm{Fe} /{ }^{54} \mathrm{Fe}\right)_{\text {sample }} /\right.$ $\left.\left({ }^{x} \mathrm{Fe} /{ }^{54} \mathrm{Fe}\right)_{\text {standard }}-1\right] \times 1000$; with $x=56$ or 57$)$. In magmatic rocks, fractionation may result from: (1) variable degrees of partial melting (Williams et al. 2005; Weyer and Ionov 2007; Dauphas et al. 2009; Teng et al. 2013); (2) fractional crystallisation (e.g. Teng et al. 2008, 2013; Schuessler et al. 2009; Sossi et al. 2012; Liu et al. 2014); and/or (3) fluid- and melt-induced mantle metasomatism (Beard and Johnson 2004; Zhao et al. 2010; Poitrasson et al. 2013). Variations of oxygen fugacity and redox conditions in the mantle also play a role in Fe isotope fractionation, as they affect mantle melting processes (Williams et al. 2004, 2005; Dauphas et al. 2009; Teng et al. 2013). MORB $\left[\delta^{56} \mathrm{Fe}\right.$ from $0.053 \pm 0.015 \%$ at $95 \%$ confidence level $(\mathrm{CL})$, to
$0.176 \pm 0.014$ at $2 \sigma$ standard error $(2 \sigma \mathrm{SE})$; Weyer and Ionov 2007; Craddock and Dauphas 2011; Sossi et al. 2012; Nebel et al. 2013; Teng et al. 2013], back-arc basin basalts (BABB) $\left[\delta^{56} \mathrm{Fe}\right.$ from $0.026 \pm 0.022$ to $0.096 \pm 0.022 \%$ at $2 \sigma$ SE; Teng et al. 2013; Nebel et al. 2013], as well as ocean island basalts (OIB) $\left[\delta^{56} \mathrm{Fe}\right.$ from $-0.011 \pm 0.030 \%$ (95\% $\mathrm{CL})$ to $+0.30 \pm 0.028 \%$ o ( $2 \sigma \mathrm{SE})$; Weyer and Ionov 2007 ; Teng et al. 2008, 2013; Schuessler et al. 2009; Konter et al. 2016], are isotopically heavier than mantle peridotites and xenoliths $\left[\delta^{56} \mathrm{Fe}=+0.014 \pm 0.018 \%\right.$ (95\%CL), Weyer and Ionov 2007; $+0.025 \pm 0.025 \%$ (95\%CL), Craddock et al. $2013 ; \delta^{57} \mathrm{Fe}=+0.05 \pm 0.01 \%$ ( $\left.2 \sigma \mathrm{SE}\right)$, corresponding to a $\delta^{56} \mathrm{Fe}$ value of c. $0.034 \pm 0.01 \%$, Sossi et al. 2016]. This difference indicates $\mathrm{Fe}$ isotope fractionation during mantle partial melting and magma differentiation (Teng et al. 2013). Fe isotope fractionation in basaltic magmas results in a preferential incorporation of the isotopically heavier, incompatible $\mathrm{Fe}^{3+}$ in the melt phase (Dauphas et al. 2009). While Fe fractionation between mantle and basaltic magmas is regulated by fractionation between $\mathrm{Fe}^{2+}$ and $\mathrm{Fe}^{3+}$, the heavier composition of OIB compared to MORB has been explained by fractional crystallisation of olivine and pyroxene in the basaltic magma, as well as by mantle source Fe isotopic heterogeneities (e.g. Teng et al. 2013).

During low-temperature (low-T) hydrothermal processes $\left(<450{ }^{\circ} \mathrm{C}\right), \mathrm{Fe}$ isotope fractionation strongly depends on redox conditions: fluids become enriched in the light $\mathrm{Fe}$ isotopes under reducing conditions (e.g. Saunier et al. 2011) because of the higher solubility of isotopically light $\mathrm{Fe}^{2+}$ in fluids relative to $\mathrm{Fe}^{3+}$. Subsequent precipitation of hydrothermal products produces $\mathrm{Fe}^{2+}$-bearing phases isotopically lighter than $\mathrm{Fe}^{3+}$-bearing phases, in which $\mathrm{Fe}$ is co-ordinated by the same ligand (e.g. O) (Polyakov and Mineev 2000). However, Fe isotopes may also fractionate significantly in aqueous solutions if changes occur in the non-redox environment, i.e. in the ligand composition (chloride, sulfide), as well as in the speciation, relative abundances, coordination number of $\mathrm{Fe}^{2+}$ and $\mathrm{Fe}^{3+}$, and in the ionic strength of the solution (Hill et al. 2010). Changes in the chemistry of Fe-bearing solutions have major implications on the isotopic composition of Fe-precipitates: $\mathrm{Fe}$ redox isotope fractionation between $\mathrm{Fe}^{2+}$ and $\mathrm{Fe}^{3+}$-bearing species decreases with decreasing chlorinity, while it is more sensitive to changes in ferric speciation than in ferrous speciation (Hill et al. 2010).

In seafloor hydrothermal fluids, $\mathrm{Fe}$ isotopic composition is generally shifted to lower $\delta^{56} \mathrm{Fe}$ (and $\delta^{57} \mathrm{Fe}$ ) values by -0.2 to $-0.7 \%$ o compared to the basaltic rocks (Rouxel et al. 2008). During low-T hydrothermal alteration of basalts, formation of $\mathrm{Fe}^{3+}$-rich secondary clays (e.g. celadonite) or Fe-hydroxides may increase the $\delta^{56} \mathrm{Fe}$ (and $\delta^{57} \mathrm{Fe}$ ) values of alteration products (Rouxel et al. 2003). Kinetic isotope fractionation during basalt alteration may 
also be responsible for preferential leaching of light $\mathrm{Fe}$ isotopes and, consequently, for an increase in $\delta^{56} \mathrm{Fe}$ (and $\delta^{57} \mathrm{Fe}$ ) compared to fresh MORB (Rouxel et al. 2003). On the other hand, sulphide products display variable light $\delta^{56} \mathrm{Fe}[-1.79 \pm 0.06$ to $-0.11 \pm 0.14 \%$; $1 \sigma$ standard deviation (SD); Rouxel et al. 2008], depending on whether they were formed in equilibrium with aqueous $\mathrm{Fe}^{2+}$ hydrothermal fluids, or were inherited from FeS precursors (Polyakov and Soultanov 2011). Rouxel et al. (2003) have shown that hydrothermal alteration processes are in turn responsible for the highly variable $\mathrm{Fe}$ isotopic composition of the bulk altered oceanic crust $\left[\delta^{57} \mathrm{Fe}\right.$ from -2.49 to $+2.05 \%$ o (mean $+0.12 \pm 0.19 \%$ at $2 \sigma \mathrm{SE} ; n=52)$; i.e. $\delta^{56} \mathrm{Fe}$ from -0.73 to $+1.39 \%$ o (mean $+0.08 \pm 0.13 \%$; $2 \sigma \mathrm{SE}$ ); including altered basalts, volcanoclastic material, veins and interflow materials] and altered oceanic basalts $\left[\delta^{56} \mathrm{Fe}\right.$ from -0.30 to $+2.05 \%$ o (mean $+0.31 \pm 0.18 \%$ at $2 \sigma \mathrm{SE} ; n=28$ ); i.e. $\delta^{56} \mathrm{Fe}$ from -0.2 to $+1.39 \%$ (mean $+0.21 \pm 0.12 \%$; $2 \sigma \mathrm{SE})]$, albeit similar in mean to the MORB value.

Studies on orogenic eclogites (Beard and Johnson 2004) and eclogite xenoliths from kimberlite pipes (Williams et al. 2009) have revealed that eclogites may conserve mantlelike $\delta^{56} \mathrm{Fe}$ values. On the contrary, $\mathrm{Fe}$ isotope fractionation is currently undetermined in metabasalts of blueschist and eclogite facies that were formed during subduction zone metamorphism and have recorded various stages of fluidrock interactions. Solubility of Fe increases with increasing chlorinity in subduction zone fluids, as $\mathrm{Fe}$ is mainly transported as Fe-chloride complexes (Manning 2004). Because chlorinity of subduction zone fluids is generally below seawater (Mottl et al. 2004; Manning 2004), Fe was considered to be relatively insoluble and immobile, contrary to Al, Si and alkalis (Schneider and Eggler 1986; Manning 2004). However, the hydrated oceanic mantle may carry significant amounts of $\mathrm{Cl}$ into the subduction zone (Scambelluri et al. 2004). Subsequent devolatilisation reactions progressively release $\mathrm{Cl}$, at the transition from oceanic serpentinites to high-pressure serpentinites, as well as under $\mathrm{P}-\mathrm{T}$ conditions of antigorite breakdown (Scambelluri et al. 2004). In this context, a recent study has revealed an unusual increase in $\delta^{56} \mathrm{Fe}$ in subducted serpentines (from $-0.02 \pm 0.15$ to $+0.08 \pm 0.11 \%$; $2 \sigma$ $\mathrm{SD}$ ) with the decrease of their $\mathrm{Fe}^{3+} / \Sigma \mathrm{Fe}$ ratio (from 0.7 to 0.5$)$ at the transition from lizardite to high-pressure antigorite (Debret et al. 2016). The authors conclude that isotopically light-Fe is carried as $\mathrm{Fe}(\mathrm{II})-\mathrm{SO}_{\mathrm{X}}$ or $\mathrm{Fe}(\mathrm{II})-\mathrm{Cl}_{2}$ species by sulfate-rich and/or hypersaline fluids that are released in the mantle wedge (Debret et al. 2016). While the $\mathrm{Fe}$ isotope database for ultrabasic and basic rocks is growing substantially, further work is required to understand Fe mobility and isotope fractionation in subduction-related basaltic rocks of blueschist and eclogite facies. During subduction, the dehydrating metabasites release significant amounts of fluids (Schmidt and Poli 1998). Characterisation of $\mathrm{Fe}$ isotope fractionation in metabasaltic rocks is expected to provide information on oceanic crust recycling in subduction zones and contribute to the current debate on the effects of subduction zone fluids on deep mantle magmatic cycles.

This study investigates hydrothermally altered metabasites (Ile de Groix, France) of prograde blueschist and eclogite facies, and retrograde greenschist facies, in order to decipher $\mathrm{Fe}$ isotope fractionation during the various stages of subduction/exhumation processes. We aim to determine whether the Fe isotope compositions of the studied rocks were modified during the various metamorphic stages and associated fluid-rock interactions (hydrothermal alteration, dehydration and rehydration reactions), or if they directly reflect the magmatic protolith composition. Finally, we discuss if and how subduction of oceanic basic rocks may generate mantle $\mathrm{Fe}$ isotope heterogeneities.

\section{Geological setting and investigated samples}

In this study, we investigate metabasic samples of blueschist, eclogite, and retrograde greenschist facies from the Ile de Groix (Armorican Massif, France), a well-known Variscan HP-LT unit (Fig. 1) (see Bosse et al. 2002; Ballèvre et al. 2003; El Korh et al. 2013; and references therein). The metabasites correspond to former hydrothermally altered enriched mid-ocean ridge basalts (E-MORB), interlayered with pelitic micaschists (Bernard-Griffiths et al. 1986; Bosse et al. 2002; El Korh et al. 2009, 2013). Because of the lack of ultrabasic and gabbroic rocks, the high-pressure rocks were interpreted as remnants of the uppermost part of an oceanic lithosphere or of basaltic lavas, emplaced during the Cambro-Ordovican rifting widely recognised along the northern Gondwana margin (El Korh et al. 2012; von Raumer et al. 2015). The Cambro-Ordovician magmatism in the southern Armorican Massif is thought to result from the intra-continental back-arc basin rifting following the closure of the ProtoRheic ocean, as recognised in the allochthonous domain of the Variscan belt (von Raumer et al. 2015). The metabasalts and metasediments were sheared off and imbricated in an accretionary prism during the Variscan subduction (El Korh et al. 2012). The rocks recorded two main metamorphic events: (1) a prograde blueschist to eclogite facies metamorphism M1 related to subduction, and (2) a greenschist facies overprint M2 related to exhumation (e.g. Barrientos and Selverstone 1993; Bosse et al. 2002). In eclogites, the peak pressure-temperature $(\mathrm{P}-\mathrm{T})$ conditions were estimated at $1.6-2.5 \mathrm{GPa}$ and $500-600{ }^{\circ} \mathrm{C}$ (using 


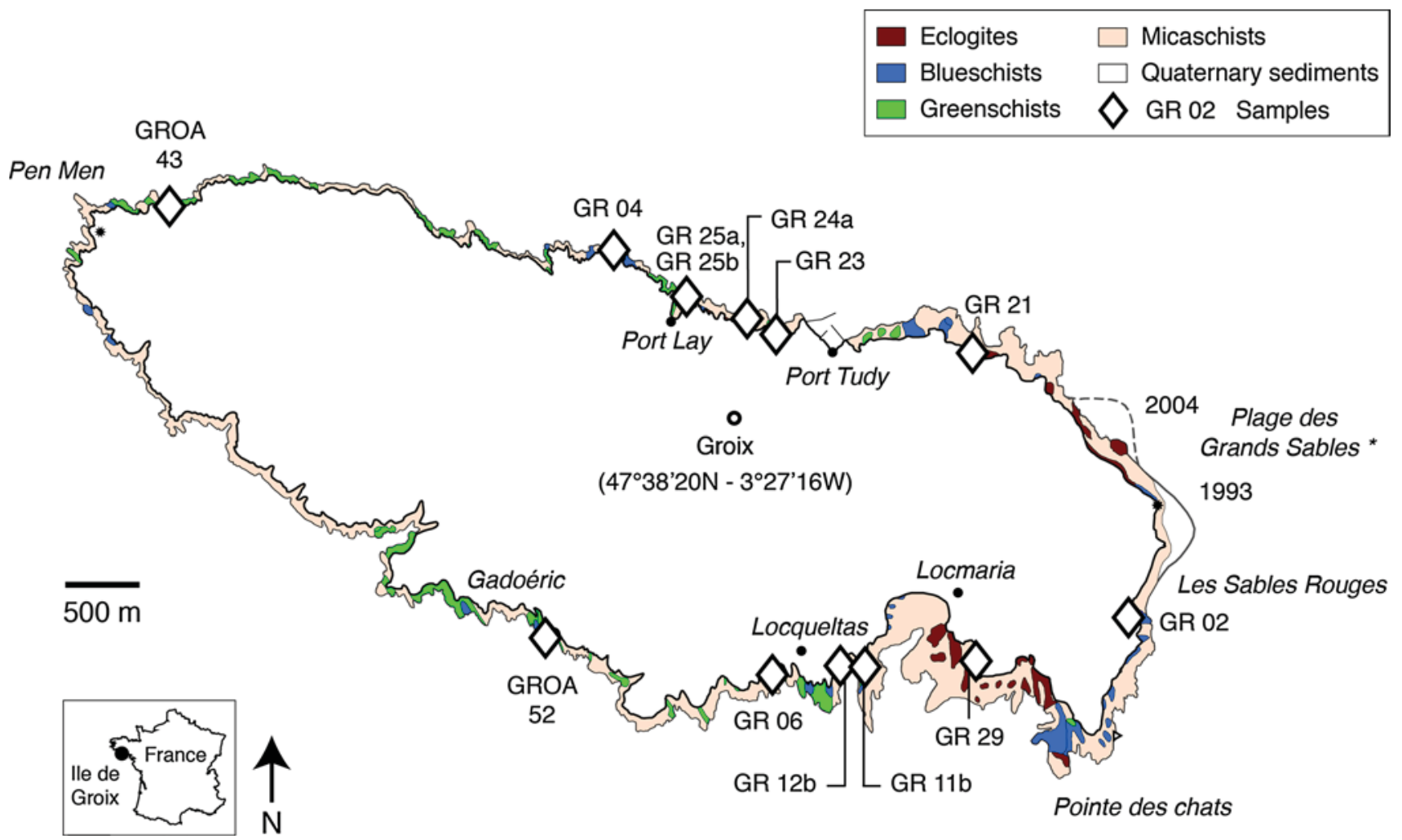

Fig. 1 Geological map of the Ile de Groix (after Audren et al. 1993; Bosse et al. 2002; El Korh et al. 2013). *The beach "Plage des Grands Sables" periodically moves with the oceanic currents

pseudo-section phase diagrams) and correspond to the blueschist to eclogite facies transition, i.e. to a $60-70 \mathrm{~km}$ depth in a subduction zone with an intermediate thermal regime (El Korh et al. 2009). In micaschists, the maximum peak P-T conditions were estimated to be 1.6-1.8 GPa, $450-500{ }^{\circ} \mathrm{C}$ using the NFMASH system (Bosse et al. 2002). Based on trace element and bulk rock $\delta^{18} \mathrm{O}$ analyses, El Korh et al. (2013) have shown that pervasive fluidrock interactions occurred as an open system during seafloor hydrothermal alteration, as well as during the early subduction metasomatism (interaction with pelite-derived fluids). During HP metamorphism, fluid migration in the metabasites is relatively slow because of their low porosity and low permeability that result in low and slow fluid fluxes (El Korh et al. 2013). Only vein channels show high fluid-rock ratios, high fluid fluxes and significant fluid-rock interactions along vein boundaries (El Korh et al. 2011). The retrograde metamorphism $\left(<1 \mathrm{GPa} ;<400-450{ }^{\circ} \mathrm{C}\right)$ was interpreted as an overprint of fluids that were already in equilibrium with the metabasites under HP-LT conditions, without infiltration of additional externally derived fluids. Metabasites that underwent pervasive alteration by pre-HP metasomatic processes, show greater effects of retrogression (El Korh et al. 2013).
Blueschist and eclogite facies metabasites are composed of garnet, glaucophane, epidote, phengite, apatite, quartz, titanite and/or rutile. Omphacite porphyroblasts are present in eclogites. Blueschist facies rocks often contain pseudomorphs after lawsonite, composed of epidote, phengite, paragonite, actinolite, and albite (Ballèvre et al. 2003). The different mineral assemblages between blueschists and eclogites result from slight differences in the composition of the protolith and/or small variations in temperature $\left(50-75{ }^{\circ} \mathrm{C}\right)$ for the peak metamorphic conditions (El Korh et al. 2009). Partial retrogression of eclogites and blueschists is evidenced by: (1) barroisite + albite symplectites replacing omphacite; (2) barroisite and actinolite overgrowths along glaucophane rims; (3) alteration of garnet to chlorite; and (4) replacement of rutile by titanite. Besides, retrograde assemblages in greenschists correspond to epidote, chlorite, actinolite, barroisite, albite, magnetite, and titanite. High-pressure garnet is partially to totally replaced by chlorite, actinolite and by a retrograde generation of epidote. "Albitic greenschists" contain large albite porphyroblasts \pm calcite, and have experienced intensive fluid-rock interactions during retrogression [for discussion, see El Korh et al. 2013, and references therein]. Overall, thirteen metabasites were analysed during this study and include five blueschists (GR 02, 04, 11b, 
Table 1 Provenance, metamorphic facies and mineral assemblage of the studied samples

\begin{tabular}{lllll}
\hline Sample & Locality* & Metamorphic facies & Mineralogical assemblage** & Reference*** \\
\hline GR 02 & Les Sables Rouges & Blueschist & Grt-gln-barr-ep-phe-qtz-ttn-rt-ap- $\diamond$ lws & {$[1]$} \\
GR 04 & Beg er Skeul & Blueschist & Grt-gln-barr-ep-phe-qtz-ttn-ap- $\diamond$ lws & {$[2]$} \\
GR 11b & Les Saisies & Blueschist & Grt-gln-barr-ep-phe-chl-ab-ttn-Fe ox (mt)- $\diamond$ lws & {$[1]$} \\
GR 12b & Porh Roëd & Blueschist & Gln-act-ep-phe-chl-ab-ttn-ap-qtz-Fe ox (hm)- $\diamond l w s$ & {$[1]$} \\
GR 25a & Port Lay & Blueschist & Grt-gln-ep-phe-act-qtz-chl-ttn-Fe ox (mt)- $\diamond$ lws & {$[1]$} \\
GR 21 & Poskedoul & Eclogite & Grt-gln-omph-barr-ep-phe-chl-qtz-Fe ox (hm, mt) & {$[1]$} \\
GR 24a & Plage du Rolaz & Eclogite & Grt-gln-barr-ep-omph-phe-chl-qtz-Fe ox (hm, mt) & {$[1]$} \\
GR 29 & Porh Giguéou & Eclogite & Grt-gln-omph-barr-ep-phe-chl-qtz-ap-rt-ttn- $\pm \diamond l w s$ & {$[1]$} \\
GR 06a & S of Locqueltas & Greenschist & Chl-ep-ab-phe-barr-qtz-Fe ox (mt)-Fe hydrox & {$[2]$} \\
GR 23 & Côte d'Héno & Greenschist & Grt-ep-chl-ab-barr-phe-act-gln-ttn-rt-Fe ox (mt) - $\diamond 1 w s$ & {$[1]$} \\
GR 25b & Port Lay & Greenschist & Grt-ep-chl-gln-barr-act-ab-qtz-ap-ttn-rt-Fe ox (mt) & {$[1]$} \\
GROA 43 & Biléric & Greenschist & Chl-Ab-cc-phe-ilm-czo-Fe ox (mt)- \pm qtz & {$[2]$} \\
GROA 52 & Gadoéric & Greenschist & Ab-chl-qtz-ep-act-barr-cc-ttn-Fe ox (mt) & {$[3]$} \\
\hline
\end{tabular}

* See Figure 1

** The mineral abbreviations are from Kretz (1983); $\diamond$ lws: pseudomorphs after lawsonite

*** [1] El Korh et al. (2009); [2] El Korh et al. (2013); [3] El Korh et al. (2011)

$12 \mathrm{~b}$ and 25a), three eclogites (GR 21, 24a and 29) and five retrograde greenschists (GR 06a, 23 and $25 \mathrm{~b}$ and albitic greenschists GROA 43 and 52) [for the detailed description of the samples see El Korh et al. 2009, 2011, 2013; and Table 1].

\section{Analytical techniques}

The $\mathrm{Fe}$ isotope ratios, in whole rocks, were measured by multi-collector inductively coupled plasma mass spectrometry (MC-ICPMS) at the CRPG-Nancy. Fe was separated following a detailed chemical procedure (MarinCarbonne et al. 2011). About $10 \mathrm{mg}$ of powdered samples were dissolved in three steps using: (1) a 2:1 mixture of $\mathrm{HF}(28 \mathrm{~N})$ and $\mathrm{HNO}_{3}(15 \mathrm{~N})$ on a hot plate at $90{ }^{\circ} \mathrm{C}$; (2) $\mathrm{HNO}_{3}(15 \mathrm{~N})$ at $60{ }^{\circ} \mathrm{C}$; and (3) $\mathrm{HCl}(7 \mathrm{~N})$ at $60{ }^{\circ} \mathrm{C}$. After total dissolution of the samples and centrifugation, $\mathrm{Fe}$ was isolated through AG-MP-1 resin-exchange chromatography columns. To avoid over-saturation of the resin, only c. 40-50 $\mu \mathrm{g}$ of Fe was introduced into the columns. Fe fractions were eluted with $\mathrm{HCl}(2 \mathrm{~N})$ and dried down. $\mathrm{Fe}$ fractions were then re-dissolved in $\mathrm{HNO}_{3}$ $(7 \mathrm{~N})$ and dried down before final dissolution in $\mathrm{HNO}_{3}$ $(0.05 \mathrm{~N})$ for MC-ICPMS analyses. Total procedural Fe blanks (including chemistry and measurements) were $<50 \mathrm{ng}$, which are negligible compared to the amount of sample Fe processed $(<0.12 \%)$. The BIR-1 basalt (Iceland) geostandard (USGS) served as secondary standard. It was dissolved and submitted to the same chemical procedure as the studied samples.
$\mathrm{Fe}$ isotopes were measured using a NeptunePlus MC-ICPMS (ThermoFisher Scientific, Germany and USA), following the procedure described in Liu et al. (2014). Samples were introduced into the MC-ICPMS via a standard nebuliser and cyclonic chamber. Ni skimmer and sampler cones in standard geometrical configuration were employed. The instrument was operated in static mode at a high resolution $(\mathrm{M} / \Delta \mathrm{M} \approx 8000)$, which allowed solving argide polyatomic interferences on $\mathrm{Fe}$ masses $\left({ }^{40} \mathrm{Ar}^{14} \mathrm{~N}\right.$ on ${ }^{54} \mathrm{Fe} ;{ }^{40} \mathrm{Ar}^{16} \mathrm{O}$ on ${ }^{56} \mathrm{Fe} ;{ }^{40} \mathrm{Ar}^{16} \mathrm{O}^{1} \mathrm{H}$ on ${ }^{57} \mathrm{Fe}$ ). The cup configuration consisted of: Low 3 $\left({ }^{53} \mathrm{Cr}\right)$, Low $2\left({ }^{54} \mathrm{Fe}\right)$, Axial $\left({ }^{56} \mathrm{Fe}\right)$ and High $1\left({ }^{57} \mathrm{Fe}\right)$. ${ }^{53} \mathrm{Cr}$ was employed to correct the isobaric interference between ${ }^{54} \mathrm{Cr}$ and ${ }^{54} \mathrm{Fe}$ intensities using a ${ }^{54} \mathrm{Cr} /{ }^{53} \mathrm{Cr}$ ratio of 0.248921 (Rosman and Taylor 1998). Gas flow rates (carrier Ar 1.06-1.08 L/min; auxiliary Ar $0.8 \mathrm{~L} /$ $\mathrm{min}$; cool Ar $15 \mathrm{~L} / \mathrm{min}$ ), torch parameters and ion lenses were optimised using a solution of the IRMM-014 ultrapure $\mathrm{Fe}$ standard. Correction coefficients between the Faraday cups were obtained by gain calibration before optimising the peak shapes and centring the peaks. Analyses were performed on $3 \mathrm{ppm}$ Fe solutions, diluted in $\mathrm{HNO}_{3}(0.05 \mathrm{~N})$. 50 cycles, with $8 \mathrm{~s}$ integration time, were measured during $10 \mathrm{~min}$, after a $13 \mathrm{~min}$ washout in $\mathrm{HNO}_{3}(0.5 \mathrm{~N})$ and 8 min washout in $\mathrm{HNO}_{3}(0.05 \mathrm{~N})$. Each sample analysis was sequentially bracketed by measurements of the IRMM-014 standard.

$\mathrm{Fe}$ isotope compositions are expressed in \%o delta values $\left(\delta^{56} \mathrm{Fe}\right.$ and $\left.\delta^{57} \mathrm{Fe}\right)$, relative to the IRMM-014 standard. Data accuracy and bulk external reproducibility (chemistry and isotope measurements) were evaluated by replicate analyses of the BIR-1 geostandard. Fe isotopic 
Table 2 Iron isotopic compositions of the studied metabasites and BIR-1 reference basalt

\begin{tabular}{|c|c|c|c|c|c|c|}
\hline \multirow[t]{2}{*}{ Samples } & & \multirow[t]{2}{*}{$n$} & \multicolumn{2}{|c|}{$\delta^{56} \mathrm{Fe}(\% o)$} & \multicolumn{2}{|c|}{$\delta^{57} \mathrm{Fe}(\% o)$} \\
\hline & & & Mean & $\pm 2 \sigma \mathrm{SE}$ & Mean & $\pm 2 \sigma \mathrm{SE}$ \\
\hline \multirow[t]{2}{*}{ BIR-1 Basalt } & Standard (USGS) & 7 & 0.061 & 0.045 & 0.101 & 0.060 \\
\hline & Reference* & & 0.053 & $0.015 * *$ & 0.087 & $0.023 * *$ \\
\hline GR02 & Blueschist & 8 & 0.223 & 0.027 & 0.334 & 0.043 \\
\hline GR04 & Blueschist & 7 & 0.248 & 0.032 & 0.376 & 0.064 \\
\hline GR11b & Blueschist & 8 & 0.325 & 0.007 & 0.512 & 0.037 \\
\hline GR12b & Blueschist & 4 & 0.194 & 0.027 & 0.261 & 0.053 \\
\hline GR25a & Blueschist & 8 & 0.246 & 0.018 & 0.380 & 0.036 \\
\hline GR21c & Eclogite & 6 & 0.160 & 0.018 & 0.254 & 0.059 \\
\hline GR24a & Eclogite & 6 & 0.182 & 0.012 & 0.278 & 0.042 \\
\hline GR29 & Eclogite & 8 & 0.184 & 0.026 & 0.278 & 0.043 \\
\hline GR06a & Greenschist & 7 & 0.279 & 0.021 & 0.406 & 0.069 \\
\hline GR23 & Greenschist & 4 & 0.174 & 0.012 & 0.294 & 0.020 \\
\hline GR25b & Greenschist & 7 & 0.214 & 0.025 & 0.337 & 0.049 \\
\hline GROA43 & Greenschist & 4 & 0.228 & 0.023 & 0.338 & 0.042 \\
\hline GROA52 & Greenschist & 7 & 0.202 & 0.014 & 0.315 & 0.037 \\
\hline
\end{tabular}

Uncertainties are $2 \sigma$ standard deviations of the mean, i.e. $2 \sigma$ standard errors (2SE)

$n$ number of replicates

* Reference values are from Craddock and Dauphas (2011)

** Analytical uncertainties are given at $95 \%$ confidence interval measurements of BIR-1 yielded $\delta^{56} \mathrm{Fe}$ and $\delta^{57} \mathrm{Fe}$ values of $+0.061 \pm 0.045$ and $+0.101 \pm 0.060 \%$ o $(2 \sigma \mathrm{SE} ; n=7)$, respectively (Table 2), that are similar to those reported in the literature (Craddock and Dauphas 2011).

\section{Results}

The Fe isotope ratios are given in Table 2. All samples have a reproducibility on $\delta^{56} \mathrm{Fe}$ better than $0.032 \%$ o $(2 \sigma$ $\mathrm{SE})$. In the $\delta^{57} \mathrm{Fe}_{\mathrm{IRMM}-014}$ vs. $\delta^{56} \mathrm{Fe}_{\text {IRMM-014 }}$ diagram (Fig. 2), all data plot within uncertainty on the slope of the equilibrium and kinetic theoretical mass fractionation lines. The metabasites have $\delta^{56} \mathrm{Fe}$ values that vary from +0.16 to $+0.33 \%$. The $\delta^{56} \mathrm{Fe}$ values generally decrease from blueschists $(+0.19$ to $+0.33 \%$ o $)$ to eclogites $(+0.16$ to $+0.18 \%$ ) , while greenschists have $\delta^{56} \mathrm{Fe}$ values $(+0.17$ to $+0.27 \%$ ) within the range of both blueschists and eclogites (Table 2; Figs. 3, 4).

Table 3 summarises the $\delta^{18} \mathrm{O}$ values, the $\mathrm{SiO}_{2}, \mathrm{Al}_{2} \mathrm{O}_{3}$, $\mathrm{Fe}_{2} \mathrm{O}_{3}^{\text {tot }}, \mathrm{FeO}$ and $\mathrm{Rb}$ concentrations, and the $\mathrm{Y} / \mathrm{Nb}$ and $(\mathrm{La} / \mathrm{Sm})_{\mathrm{PM}}$ ratios (El Korh et al. 2009, 2011, 2013, 2017), as well as the $\mathrm{Fe}^{3+} / \Sigma \mathrm{Fe}$ values (El Korh et al. 2017), that will be discussed below. For the whole set of samples, the $\delta^{56} \mathrm{Fe}$ values do not show any well-defined linear correlation with the $\mathrm{Al}_{2} \mathrm{O}_{3}, \mathrm{SiO}_{2}$ and $\mathrm{Fe}_{2} \mathrm{O}_{3}^{\text {tot }}$ contents (Fig. 3a-c), nor with the $\mathrm{Fe}^{3+} / \Sigma \mathrm{Fe}$ and $\mathrm{Fe} /$ Ti ratios (Fig. 3d, e). A trend can still be identified: the

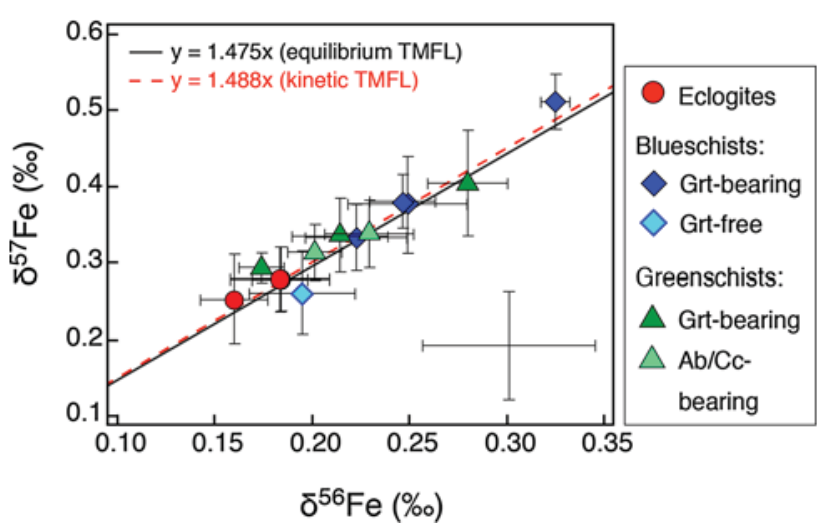

Fig. $2 \delta^{57} \mathrm{Fe}_{\mathrm{IRMM}-014}$ vs. $\delta^{56} \mathrm{Fe}_{\mathrm{IRMM}-014}$ diagram for the studied samples from the Ile de Groix. Error bars are at $2 \sigma$ SE external reproducibility, based on replicate analyses. The data plot within uncertainty along the equilibrium and kinetic theoretical mass fractionation lines (TMFL) defined by equations $\delta^{57} \mathrm{Fe}_{\text {IRMM-014 }}=(1 /$ $\left.\mathrm{m}^{57} \mathrm{Fe}-1 / \mathrm{m}^{54} \mathrm{Fe}\right) /\left(1 / \mathrm{m}^{56} \mathrm{Fe}-1 / \mathrm{m}^{54} \mathrm{Fe}\right) \times \delta^{56} \mathrm{Fe}$ IRMM-014 $\approx 1.475 \times$ $\delta^{56} \mathrm{Fe}_{\text {IRMM-014 }}$ (equilibrium TMFL) and $\delta^{57} \mathrm{Fe}_{\mathrm{IRMM}-014}=\left[\ln \left(\mathrm{m}^{57} \mathrm{Fe} /\right.\right.$ $\left.\left.\mathrm{m}^{54} \mathrm{Fe}\right) / \ln \left(\mathrm{m}^{56} \mathrm{Fe} / \mathrm{m}^{54} \mathrm{Fe}\right)\right] \times \delta^{56} \mathrm{Fe}_{\mathrm{IRMM}-014} \approx 1.488 \times \delta^{56} \mathrm{Fe}_{\mathrm{IRMM}-014}$ (kinetic TMFL). The long-term reproducibility at $2 \sigma$ SE for the BIR-1 geostandard $\left( \pm 0.045 \%\right.$ o for $\delta^{56} \mathrm{Fe}$ and $\pm 0.060 \%$ o for $\left.\delta^{57} \mathrm{Fe}\right)$ is represented as error bars

$\delta^{56} \mathrm{Fe}$ appears to increase with the decrease of $\mathrm{Fe}_{2} \mathrm{O}_{3}$. Besides, the $\delta^{56} \mathrm{Fe}$ decreases from blueschists to eclogites with decreasing $\mathrm{Al}_{2} \mathrm{O}_{3}$ content and with increasing $\mathrm{SiO}_{2}$ content (Fig. 3a, b). Despite the absence of any linear 

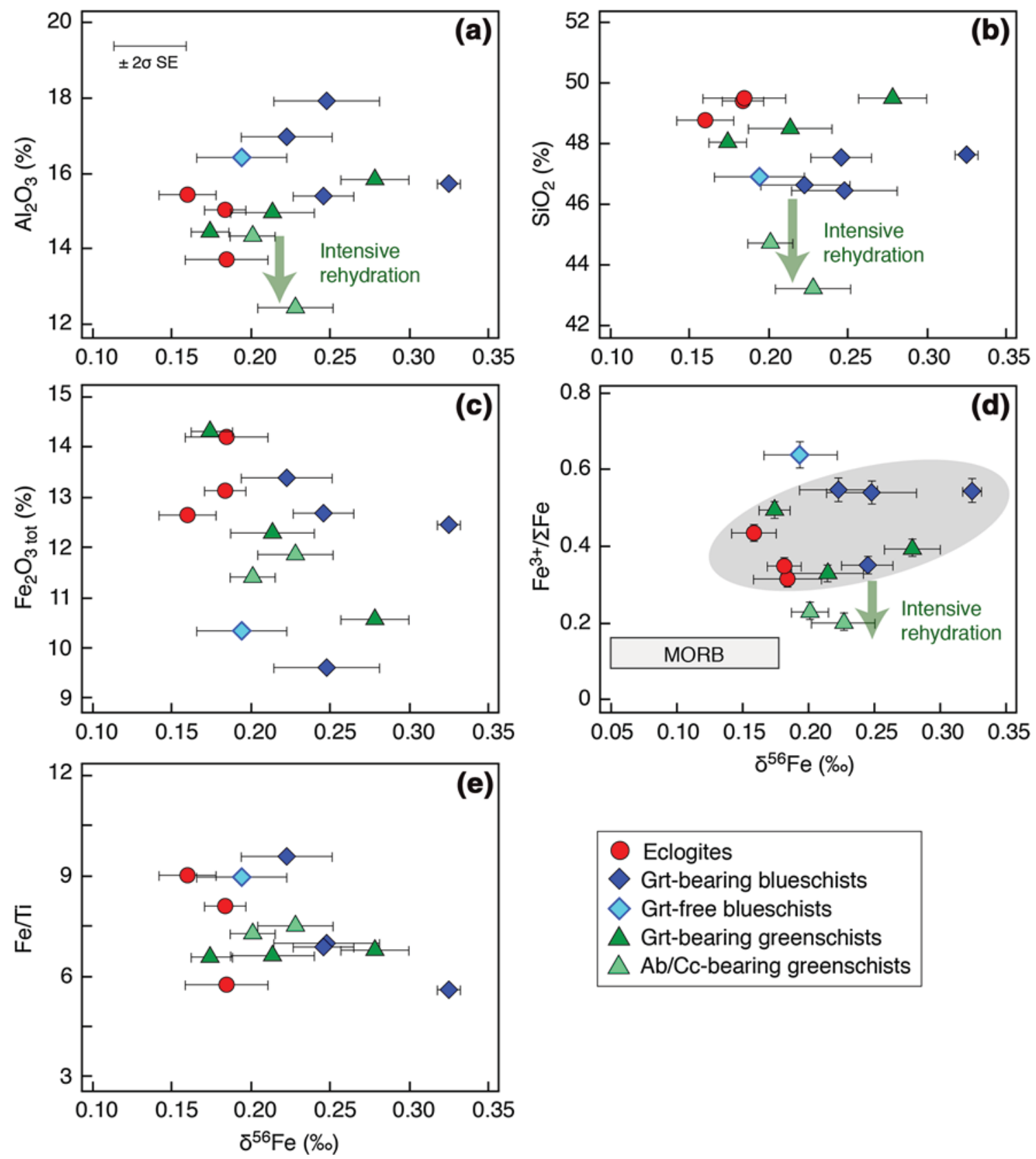

Fig. $3 \mathrm{Al}_{2} \mathrm{O}_{3}\left(\right.$ a) $, \mathrm{SiO}_{2}(\mathbf{b}), \mathrm{Fe}_{2} \mathrm{O}_{3}^{\text {tot }}(\mathbf{c}), \mathrm{Fe}^{3+} / \Sigma \mathrm{Fe}(\mathbf{d})$ and $\mathrm{Fe} / \mathrm{Ti}(\mathbf{e})$ vs. $\delta^{56} \mathrm{Fe}$ in the metabasites of the Ile de Groix. The corresponding data are reported in Tables 2 and 3. Error bars and long-term reproducibility (BIR-1) on plot (a) are the same as in Fig. 2. Uncertainties for the $\mathrm{Fe}^{3+} / \Sigma \mathrm{Fe}$ ratio are c. $0.5 \%$. The grey field in the $\mathrm{Fe}^{3+} / \Sigma \mathrm{Fe}$ vs. $\delta^{56} \mathrm{Fe}$ diagram (d) represents the garnet-bearing metabasites. The

correlation between $\delta^{56} \mathrm{Fe}$ and $\mathrm{Fe}^{3+} / \Sigma \mathrm{Fe}$ values (Fig. 3d), it is graphically evident that blueschists have generally higher $\delta^{56} \mathrm{Fe}$ and $\mathrm{Fe}^{3+} / \Sigma \mathrm{Fe}$ values than eclogites (Fig. 3d; Table 3). The garnet-free blueschist GR 12b, with the highest $\mathrm{Fe}^{3+} / \Sigma \mathrm{Fe}$ ratio, has a $\delta^{56} \mathrm{Fe}$ value within the same range as other metabasites.

$\mathrm{Fe}^{3+} / \Sigma \mathrm{Fe}$ values for MORB are from Christie et al. (1986), Bezos and Humler (2005), Kelley and Cottrell (2009), and Cottrell and Kelley (2011). The $\delta^{56} \mathrm{Fe}$ values for MORB are from Weyer and Ionov (2007), Craddock and Dauphas (2011), Sossi et al. (2012), Nebel et al. (2013), and Teng et al. (2013)

Greenschists have major element compositions within the range of both blueschists and eclogites, except albite-/calcite-bearing greenschists (GROA 43 and 52), which underwent intensive fluid-rock interactions during retrogression (Fig. 3a, b). While albite-/calcite-bearing greenschists show the lowest $\mathrm{Fe}^{3+} / \Sigma \mathrm{Fe}$ ratios, their $\mathrm{Fe}$ 

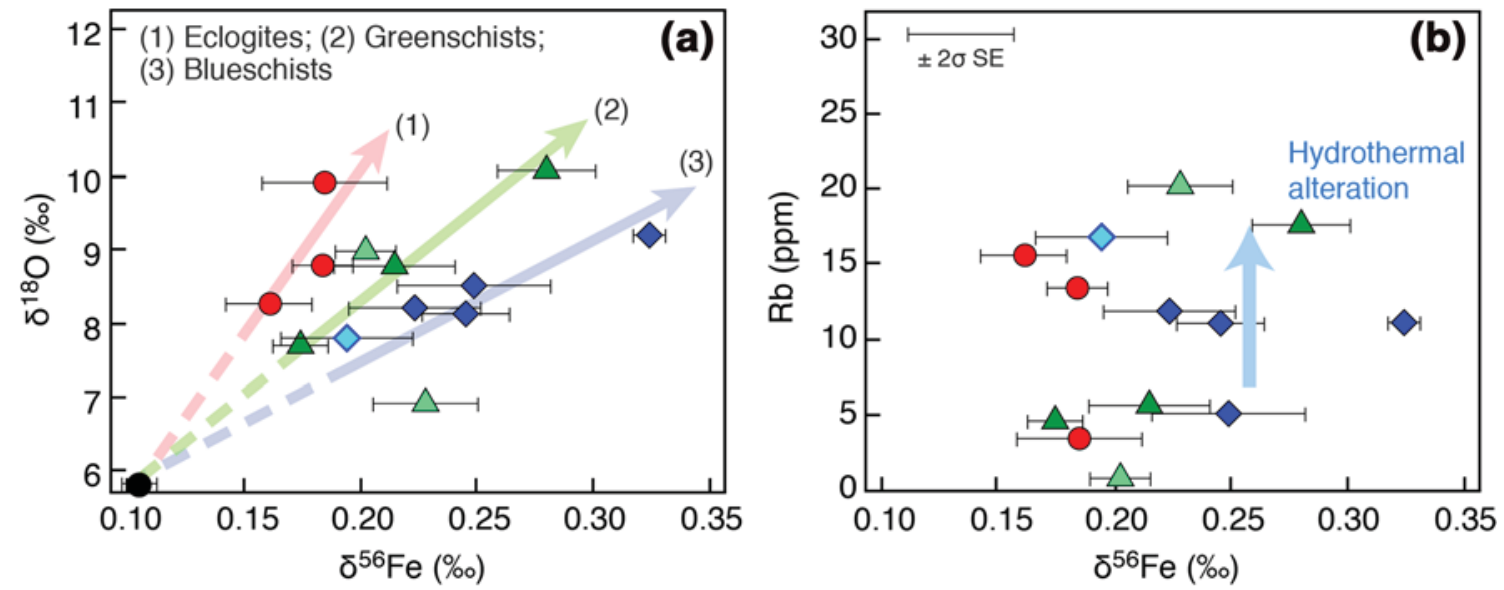

$\begin{array}{ll}\text { Eclogites } & \triangle \text { Grt-bearing greenschists } \\ \text { Grt-bearing blueschists } & \triangle \text { Ab/Cc-bearing greenschists } \\ \text { Grt-free blueschists } & \triangle \mathrm{N}-\mathrm{MORB}\end{array}$

Fig. $4 \delta^{18} \mathrm{O}(\mathbf{a})$ and $\mathrm{Rb}(\mathbf{b})$ vs. $\delta^{56} \mathrm{Fe}$ in the metabasites of the Ile de Groix. The corresponding data are reported in Tables 2 and 3. Error bars are at $2 \sigma \mathrm{SE}$ external reproducibility. Error bars and long-term reproducibility (BIR-1) on plot (b) are the same as in Fig. 2. In the $\delta^{18} \mathrm{O}$ vs. $\delta^{56} \mathrm{Fe}$ diagram, distinct trends are observed for each lithology and originate from a common isotopic composition in $\delta^{56} \mathrm{Fe} \approx+0.10$ to $+0.12 \%$ and $\delta^{18} \mathrm{O} \approx+5.8$ to $+6.0 \%$, similar to that of MORB.
The MORB end-member was included in the calculation of the regression lines for each lithology: blueschists (blue arrow; slope $15.38 ; R^{2} 0.938$ ), eclogites (red arrow; slope $45.71 ; R^{2} 0.937$ ) and greenschists (green arrow; slope 25.01; $R^{2}$ 0.959; calcite-bearing greenschist GROA 43 excluded). d In the $\mathrm{Rb}$ vs. $\delta^{56} \mathrm{Fe}$ diagram, the $\mathrm{Rb}$ abundances increase with the degree of hydrothermal alteration. No correlation is observed with the $\delta^{56} \mathrm{Fe}$ values

Table $3 \mathrm{SiO}_{2}, \mathrm{Al}_{2} \mathrm{O}_{3} \mathrm{Fe}_{2} \mathrm{O}_{3}$ tot, $\mathrm{FeO}$ and $\mathrm{Rb}$ concentrations, $\mathrm{Fe}^{3+} / \Sigma \mathrm{Fe}, \mathrm{Y} / \mathrm{Nb}$ and $(\mathrm{La} / \mathrm{Sm})_{\mathrm{PM}}$ ratios, and $\delta^{18} \mathrm{O}$ of the studied metabasites

\begin{tabular}{|c|c|c|c|c|c|c|c|c|c|}
\hline Reference* & $\begin{array}{l}\mathrm{SiO}_{2} \\
{[1,2,3]}\end{array}$ & $\begin{array}{l}\mathrm{Al}_{2} \mathrm{O}_{3} \\
{[1,2,3]}\end{array}$ & $\begin{array}{l}\mathrm{Fe}_{2} \mathrm{O}_{3} \text { tot } \\
{[1,2,3]}\end{array}$ & $\begin{array}{l}\mathrm{Fe}^{3+} / \Sigma \mathrm{Fe}^{* * *} \\
{[4]}\end{array}$ & $\begin{array}{l}\mathrm{Fe} / \mathrm{Ti} \\
{[1,2,3]}\end{array}$ & $\begin{array}{l}\mathrm{Y} / \mathrm{Nb} \\
{[1,2,3]}\end{array}$ & $\begin{array}{l}(\mathrm{La} / \mathrm{Sm})_{\mathrm{PM}} * * * \\
{[1,2,3]}\end{array}$ & $\begin{array}{l}\mathrm{Rb} \\
{[1,2,3]}\end{array}$ & $\begin{array}{l}\delta^{18} \mathrm{O}(\% \circ) \\
{[1,2,3]}\end{array}$ \\
\hline \multicolumn{10}{|l|}{ Blueschists } \\
\hline GR02 & 46.61 & 16.96 & 13.37 & 0.54 & 9.48 & 8.97 & 1.14 & 12 & 8.2 \\
\hline GR04 & 46.44 & 17.90 & 9.59 & 0.53 & 6.99 & 3.58 & 1.41 & 5.3 & 8.5 \\
\hline GR11b & 47.63 & 15.72 & 12.45 & 0.54 & 5.58 & 2.50 & 1.73 & 11 & 9.2 \\
\hline GR12b & 46.91 & 16.42 & 10.34 & 0.64 & 8.96 & 1.26 & 3.85 & 17 & 7.8 \\
\hline GR25a & 47.56 & 15.40 & 12.67 & 0.35 & 6.91 & 6.04 & 1.11 & 11 & 8.13 \\
\hline \multicolumn{10}{|l|}{ Eclogites } \\
\hline GR21c & 48.75 & 15.43 & 12.65 & 0.43 & 9.00 & 11.1 & 0.73 & 16 & 8.25 \\
\hline GR24a & 49.39 & 15.05 & 13.12 & 0.35 & 8.08 & 11.49 & 1.18 & 13 & 8.78 \\
\hline GR29 & 49.48 & 13.72 & 14.18 & 0.32 & 5.74 & 9.76 & 1.03 & 3.6 & 9.92 \\
\hline \multicolumn{10}{|l|}{ Greenschists } \\
\hline GR06a & 49.51 & 15.84 & 10.56 & 0.39 & 6.85 & 1.69 & 1.82 & 18 & 10.09 \\
\hline GR23 & 48.04 & 14.47 & 14.30 & 0.50 & 6.67 & 10.03 & 0.85 & 4.6 & 7.71 \\
\hline GR25b & 48.49 & 14.98 & 12.26 & 0.33 & 6.66 & 5.62 & 1.02 & 5.9 & 8.76 \\
\hline GROA43 & 43.22 & 12.43 & 11.86 & 0.20 & 7.62 & 8.11 & 0.90 & 21 & 6.91 \\
\hline GROA52 & 44.74 & 14.35 & 11.40 & 0.23 & 7.35 & 8.69 & 0.90 & 1.2 & 8.98 \\
\hline
\end{tabular}

$\mathrm{SiO}_{2}, \mathrm{Al}_{2} \mathrm{O}_{3}, \mathrm{Fe}_{2} \mathrm{O}_{3 \text { tot }}$, and $\mathrm{FeO}$ in wt \%; $\mathrm{Rb}$ in ppm; $\mathrm{Fe} / \mathrm{Ti}, \mathrm{Y} / \mathrm{Nb},(\mathrm{La} / \mathrm{Sm})_{\mathrm{PM}}$ weight ratios in ppm/ppm

* Data from: El Korh et al. 2009 [1]; El Korh et al. 2013 [2]; El Korh et al. 2011 [3]; El Korh et al. 2017 [4]

** The $\mathrm{Fe}^{3+} / \Sigma \mathrm{Fe}$ ratios were calculated using the whole rock $\mathrm{Fe}_{2} \mathrm{O}_{3}$ tot content, as well as the $\mathrm{FeO}$ content measured by volumetric method (see El Korh et al. 2017)

*** $(\mathrm{La} / \mathrm{Sm})_{\mathrm{PM}}$ normalised to the Primitive mantle (normalisation values are from Sun and McDonough 1989) 
isotope values are similar to the $\delta^{56} \mathrm{Fe}$ values recorded by the other metabasites.

Even if the $\delta^{56} \mathrm{Fe}$ and $\delta^{18} \mathrm{O}$ do not correlate for the whole set of samples, a positive correlation between $\delta^{56} \mathrm{Fe}$ and $\delta^{18} \mathrm{O}$ is observed within each metamorphic facies, all trends arising from a common isotopic composition in $\delta^{56} \mathrm{Fe} \approx+0.10$ to $+0.12 \%$ and $\delta^{18} \mathrm{O} \approx+5.8$ to $+6.0 \%$ o, similar to that of MORB (Fig. 4a). The slope of the fractionation line increases from blueschists $(15.38 \pm 1.97)$ to eclogites $(45.71 \pm 7.89)$. Greenschists, deriving either from blueschists or eclogites, have a slope with an intermediate value $(25.01 \pm 2.99)$. Only sample GROA 43, which displays abundant retrograde calcite formation, does not plot along the fractionation line determined for greenschists.

The $\mathrm{Rb}$ content in metabasites (1.2 to $21 \mathrm{ppm}$; El Korh et al. 2009, 2011, 2013) does not correlate with the $\delta^{56} \mathrm{Fe}$ values (Fig. 4b), this, independently of the metamorphic facies.

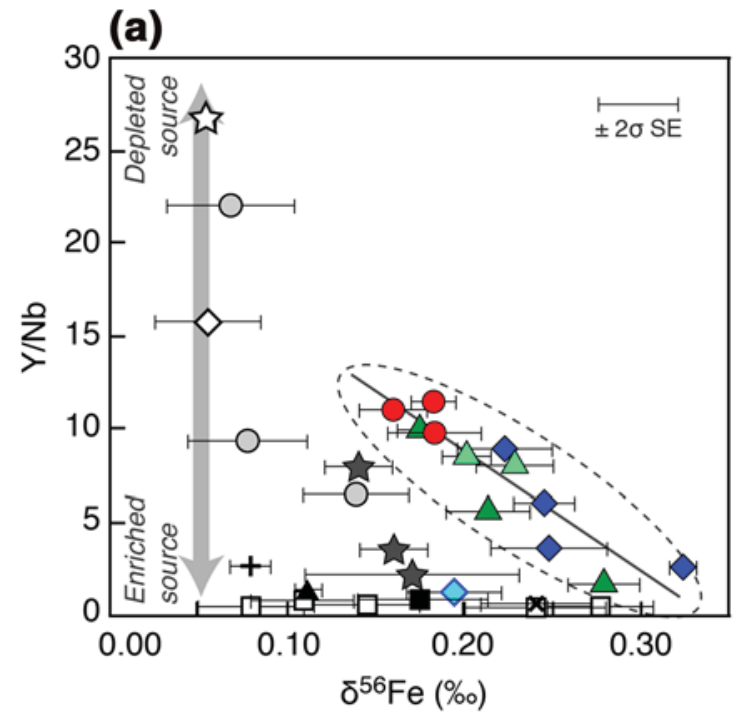

A well-defined negative correlation is observed between the $\delta^{56} \mathrm{Fe}$ values and the $\mathrm{Y} / \mathrm{Nb}$ ratios in the studied metabasites, except for the garnet-free blueschist GR $12 \mathrm{~b}\left(R^{2}\right.$ coefficient of 0.8123) (Fig. 5a). A good correlation is also observed between the $\delta^{56} \mathrm{Fe}$ values and the $(\mathrm{La} / \mathrm{Sm})_{\mathrm{PM}}$ ratio ( $R^{2}$ coefficient of 0.7308 ) (Fig. 5b). All the $\delta^{56} \mathrm{Fe}$ values are shifted by $+0.06-0.10 \%$ to higher values, in comparison to MORB at the same $\mathrm{Y} / \mathrm{Nb}$ or $(\mathrm{La} / \mathrm{Sm})_{\mathrm{PM}}$ ratio (Figs. 5a, b).

\section{Discussion}

\section{Fe isotope fractionation in the studied metabasites during subduction zone metamorphism}

Different processes need to be considered to explain the high $\delta^{56} \mathrm{Fe}$ values in the metabasites of the Ile de Groix: (1) a pre-subduction overprint related to the

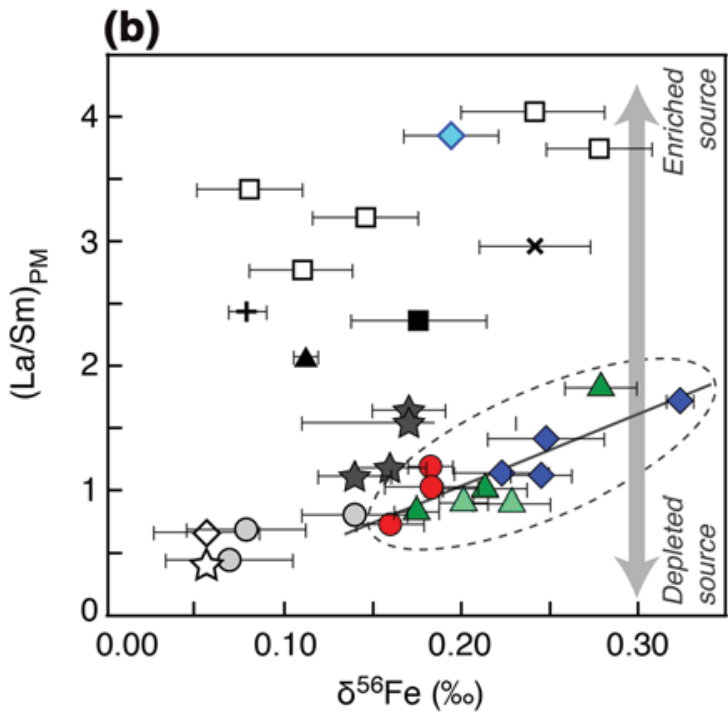

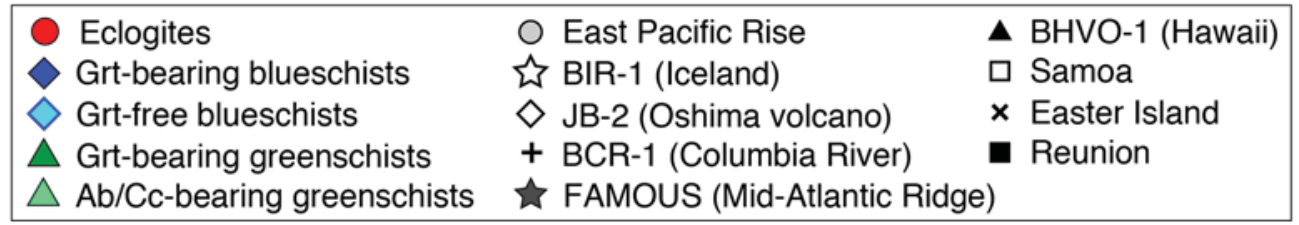

Fig. $5 \mathrm{Y} / \mathrm{Nb}$ (a) and $(\mathrm{La} / \mathrm{Sm})_{\mathrm{PM}}($ b) $)$ vs. $\delta^{56} \mathrm{Fe}$ in the metabasites of the Ile de Groix compared to a series of tholeiitic (BIR-1, East Pacific Rise, JB-2, BCR, FAMOUS-MAR: "French-American MidOcean Undersea Study-Mid-Atlantic Ridge") and alkaline basalts (BHVO-1, Samoa, Easter Island, Reunion). Data for the Ile de Groix samples (surrounded by dotted lines) are reported in Tables 2 and 3. The ${ }^{56} \mathrm{Fe}$ values are from Weyer and Ionov (2007) for East Pacific Rise, JB-2, Easter Island and Reunion samples; from Konter et al. (2016) for Samoa samples; and from Nebel et al. (2013) for the FAMOUS basalts (E-MORB). The mean $\delta^{56} \mathrm{Fe}$ values for BIR1, BHVO-1 and BCR basalts are from Weyer and Ionov (2007), and from Craddock and Dauphas (2011). The trace element compositions are from: Govindaraju (1994) for BIR-1, BHVO-1 and BCR basalts;
Imai et al. (1995) for JB-2 basalt; Haase (2002) for East Pacific Rise and Easter Island samples; Fretzdorff and Haase (2002) for Reunion sample; Langmuir et al. (1977) for the FAMOUS basalts; and Jackson et al. (2007) for Samoa samples. The long-term reproducibility (BIR-1) is represented as an error bar on plot (a). Error bars are at $2 \sigma$ SE external reproducibility, and at $95 \%$ confidence level for East Pacific Rise, Reunion Easter Island and JB-2 basalts. a The $\delta^{56} \mathrm{Fe}$ values of the metabasites of the Ile de Groix, except for the garnetfree blueschist GR 12b, show excellent correlation with the $\mathrm{Y} / \mathrm{Nb}$ (slope $-63.65 \pm 9,67 ; R^{2} 0.8123$ ) ratios. b A good correlation is also observed between the $\delta^{56} \mathrm{Fe}$ values and the $(\mathrm{La} / \mathrm{Sm})_{\mathrm{PM}}$ ratio (slope $\left.6.13 \pm 0.68 ; R^{2} 0.7308\right)$. Only the garnet-free blueschist GR $12 \mathrm{~b}$ plots away from the line 
pervasive low-T hydrothermal alteration; (2) Fe isotope fractionation during devolatilisation reactions related to the HP metamorphism and/or; (3) Fe isotope fractionation during rehydration reactions related to exhumation.

\section{Effect of hydrothermal alteration on Fe isotope fractionation}

Pervasive pre-HP hydrothermal processes in the metabasites of the Ile de Groix (low-T seafloor hydrothermal alteration and early-subduction metasomatism related to sediment-derived fluids) were responsible for an increase in large ion lithophile element (LILE: Cs, Rb, Ba) and $\delta^{18} \mathrm{O}$ values (El Korh et al. 2013).

According to Rouxel et al. (2003), the altered oceanic crust displays variable $\mathrm{Fe}$ isotopic composition, with $\delta^{57} \mathrm{Fe}$ from -2.49 to $+2.05 \%$ (i.e. $\delta^{56} \mathrm{Fe}$ from -1.69 to $+1.39 \%$ ) in alteration products, hydrothermal deposits and veins, and altered oceanic crust. Thus, we have investigated whether the range in $\delta^{56} \mathrm{Fe}$ values for the metabasites of the Ile de Groix (heavier by c. +0.10 to $0.20 \%$ o compared to MORB; Figs. 4, 5, 6) may highlight variable degrees of hydrothermal alteration.

A good $\delta^{18} \mathrm{O}-\delta^{56} \mathrm{Fe}$ correlation can be observed for each metamorphic facies, but not for the whole sample set (Fig. 4a). The $\delta^{18} \mathrm{O}$ increased in all metabasites during the low-T hydrothermal alteration, with overlapping $\delta^{18} \mathrm{O}$ values for blueschists, eclogites and greenschists (El Korh et al. 2013). Williams et al. (2009) found highly variable $\mathrm{Fe}$ isotope compositions in bulk mantle eclogite xenoliths ( $T$ of $935-1401{ }^{\circ} \mathrm{C}$ ) from kimberlite pipes $\left(\delta^{57} \mathrm{Fe}\right.$ from $-0.59 \pm 0.12$ to $+0.33 \pm 0.09 \%$; $\delta^{56} \mathrm{Fe}$ from $-0.38 \pm 0.42$ to $+0.26 \pm 0.20 \%$; $2 \sigma \mathrm{SD})$, and a positive correlation between $\delta^{57} \mathrm{Fe}$ and $\delta^{18} \mathrm{O}$. However, they did not observe any $\mathrm{Fe}$ isotope fractionation, nor any correlation with the $\delta^{18} \mathrm{O}$ in hydrothermally altered oceanic basaltic dykes, despite large uncertainties in $\mathrm{Fe}$ isotope ratios $\left(\delta^{57} \mathrm{Fe}\right.$ from $+0.10 \pm 0.07$ to $+0.33 \pm 0.13 \% ; \quad \delta^{56} \mathrm{Fe}$ from $+0.11 \pm 0.11$ to $+0.31 \pm 0.19 \%$; $2 \sigma \mathrm{SD})$. Consequently, Williams et al. (2009) have interpreted the correlation between $\delta^{18} \mathrm{O}$ and $\delta^{57} \mathrm{Fe}$ as the result of isotope fractionation by disequilibrium partial melting in the mantle rather than the effects of metasomatism. By contrast, Gréau et al. (2011) have interpreted the positive correlation between $\mathrm{Fe}$ and $\mathrm{O}$ isotopes in the same series of eclogites as the result of intensive mantle metasomatism by high- $\delta^{18} \mathrm{O}$ carbonatite- or kimberlite-related fluids/melts.

Even if our data are similar within uncertainty to the results of Williams et al. (2009) (Fig. 6), the P-T conditions of blueschist- and eclogite-facies metamorphism (1.6-2.5 GPa; 500-600 ${ }^{\circ} \mathrm{C}$; El Korh et al. 2009) in the metabasites of the Ile de Groix were too low to generate partial melting. Moreover, the $\delta^{18} \mathrm{O}$ values of the metabasites of the Ile de Groix are significantly heavier than MORB and mantle values by $1.1-4.3 \%$. Such a large difference argues against fractionation at high temperature during partial melting, which is not a feasible mechanism to generate large $\delta^{18} \mathrm{O}$ variability. Here we explore different modes of isotope fractionation of $\mathrm{O}$ and Fe (Fig. 4a). One possible explanation is that $\mathrm{O}$ and $\mathrm{Fe}$ fractionation did not occur concomitantly. While $\mathrm{O}$ isotope fractionation in the metabasites is highly sensitive to low- $\mathrm{T}$ seafloor hydrothermal alteration, $\mathrm{Fe}$ isotope fractionation may have been limited and only reflect variations in the protolith composition (Fig. 5a, b). A second possibility is that the variable $\mathrm{Fe}$ isotope compositions result from changes in the redox conditions (blueschists and eclogites: $\mathrm{Fe}^{3+}$ / $\Sigma \mathrm{Fe}=0.32-0.65)$ during hydrothermal alteration of basaltic protoliths (Fig. 3d). Thus, the various degrees of $\mathrm{Fe}$ oxidation states might have been responsible for the precipitation of different alteration products (reduced $\mathrm{Fe}^{2+}$-rich sulphides, oxidised $\mathrm{Fe}^{3+}$-rich oxides and/or hydroxides) with variable $\delta^{56} \mathrm{Fe}$ values during seafloor hydrothermal alteration. The decrease of the slope of the fractionation line in the $\delta^{18} \mathrm{O}$ vs. $\delta^{56} \mathrm{Fe}$ graph from eclogites to blueschists could reflect different diffusion rates and kinetic isotope fractionation of $\mathrm{Fe}$ compared to $\mathrm{O}$ during hydrothermal alteration and, possibly, during early-subduction interaction with sediment-derived fluids (Fig. 4a). A superimposed effect of variable temperatures of hydrothermal alteration might also be envisaged, even if all metabasites have $\delta^{18} \mathrm{O}$ within the typical range of low- $\mathrm{T}$ $\left(<450{ }^{\circ} \mathrm{C}\right)$ hydrothermal alteration (El Korh et al. 2013).

The LILE ( $\mathrm{Cs}, \mathrm{Rb}$ and $\mathrm{Ba}$ ) abundances in the metabasites of the Ile de Groix have increased during hydrothermal alteration (El Korh et al. 2013). However, the $\delta^{56} \mathrm{Fe}$ values do not correlate with LILE contents in the studied metabasites (Fig. 4b; Electronic Appendix; Fig. A2). The fluid-mobile LILE abundances may have been disturbed during high-pressure dehydration reactions, contrary to O isotopes (El Korh et al. 2013). Despite this lack of correlation, the range of $\mathrm{Fe}$ isotopic compositions of the metabasites of the Ile de Groix, heavier by c. 0.06$0.10 \%$ compared to MORB and OIB (Figs. 4, 5, 6), may still highlight variable degrees of hydrothermal alteration.

The studied metabasites have $\delta^{56} \mathrm{Fe}$ comparable to the values obtained by Williams et al. (2009) for hydrothermally altered basaltic dykes $(+0.12$ to $+0.31 \%$ o $)$ (Fig. 6). By contrast, our data show smaller variations than those of Rouxel et al. (2003), who measured a large range of $\delta^{57} \mathrm{Fe}$ from -0.30 to $+2.05 \%$ o (i.e. $\delta^{56} \mathrm{Fe}$ from -0.20 to $+1.39 \%$ ) in altered oceanic basalts. The intensively altered basalts that show the heaviest $\mathrm{Fe}$ isotopic compositions are generally depleted in $\mathrm{Fe}_{2} \mathrm{O}_{3}^{\text {tot }}$ compared to fresh MORB 


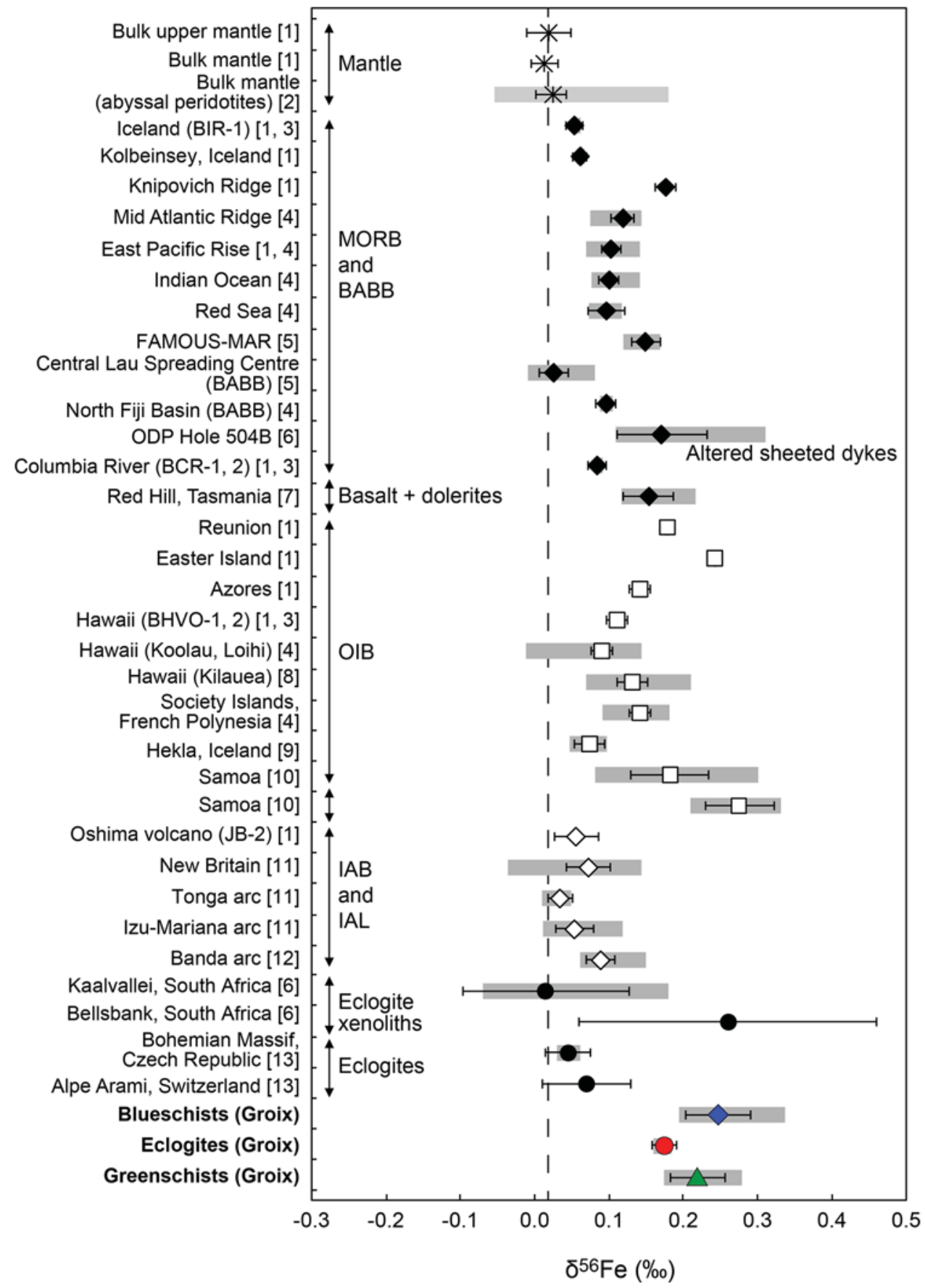

Fig. 6 Comparison of the $\mathrm{Fe}$ isotope composition of the studied blueschists, eclogites and greenschists with published values for the bulk mantle rocks, mid-ocean ridge basalts (MORB), back-arc basin basalts (BABB), ocean island basalts (OIB), island arc basalts and lavas (IAB and IAL), and basic eclogites. Grey bars correspond to the range of values for each set of samples. Mean $\delta^{56} \mathrm{Fe}$ values were calculated using the data from: [1] Weyer and Ionov (2007); [2] Craddock et al. (2013); [3] Craddock and Dauphas (2011); [4] Teng et al. (2013); [5] Nebel et al. (2013) (sample FAMOUS-MAR: "French-American Mid-Ocean Undersea Study-Mid-Atlantic Ridge"); [6] Williams et al. (2009); [7] Sossi et al. (2012); [8] Teng et al. (2008); [9] Schuessler et al. (2009); [10] Konter et al. (2016);
[11] Dauphas et al. (2009); [12] Nebel et al. (2015); [13] Beard and Johnson (2004). Data for the altered oceanic crust from Rouxel et al. (2003) are not included in the figure because of the large variation of $\mathrm{Fe}$ isotopic values $\left[\delta^{56} \mathrm{Fe}\right.$ from -0.73 to $+1.39 \%$, with a mean of $+0.08 \pm 0.13(2 \sigma \mathrm{SE})$, for the bulk oceanic crust; from -0.20 to $+1.39 \%$, with a mean of $+0.21 \pm 0.12(2 \sigma \mathrm{SE})$, for altered basalts]. Error bars (thin black lines) are represented at $2 \sigma \mathrm{SE}$, and at $95 \%$ confidence level for bulk mantle [1], Knipovich Ridge [1] and JB-2 [1] samples. Error bars for the eclogite xenolith from Bellsbank [6] are at $2 \sigma \mathrm{SD}$. The black dotted line represents the bulk mantle Fe isotopic composition 
(Rouxel et al. 2003). The $\mathrm{Fe}_{2} \mathrm{O}_{3}^{\text {tot }}$ content and $\mathrm{Fe}^{3+} /$ $\Sigma \mathrm{Fe}$ ratios of the metabasites of the Ile de Groix do not correlate with markers of hydrothermal alteration $\left(\delta^{18} \mathrm{O}\right.$ or $\mathrm{Rb}$ content; Electronic Appendix Fig. A3). Thus, there is no clear evidence of any $\mathrm{Fe}$ leaching or addition in the metabasites during hydrothermal alteration, even if the studied samples have heterogeneous $\mathrm{Fe}$ concentrations $\left(\mathrm{Fe}_{2} \mathrm{O}_{3}^{\text {tot }}\right.$ from 9.59 to $14.30 \%$; Table 3; Fig. 3c), all within the typical range of ocean floor basalts $\left(\mathrm{Fe}_{2} \mathrm{O}_{3}^{\text {tot }}\right.$ from 8.73 to $17.36 \%$; Jenner and O'Neill 2012). The metabasites have $\mathrm{Fe}^{3+} / \Sigma \mathrm{Fe}$ ratios (0.20-0.64; El Korh et al. 2017) that are significantly higher than those of MORB (0.07-0.16; Christie et al. 1986; Bezos and Humler 2005; Kelley and Cottrell 2009; Cottrell and Kelley 2011) (Fig. 3d). It is difficult to determine exactly during which process $\mathrm{Fe}$ oxidation occurred (seafloor and sub-seafloor hydrothermal alteration, early subduction hydrothermal processes, HP metamorphism). If Fe oxidation was triggered by low-T (sub-) seafloor hydrothermal alteration after protolith emplacement, it would have probably resulted from the precipitation of $\mathrm{Fe}^{3+}$-rich phases during hydrothermal alteration, with $\mathrm{Fe}^{3+}$-rich phases preferentially incorporating the heavier isotopes (Polyakov and Mineev 2000). The $\delta^{56} \mathrm{Fe}$ values do not correlate with the Fe redox state for the entire series of metabasites (Fig. 3d). Thus, two hypotheses can explain their high $\mathrm{Fe}^{3+} / \Sigma \mathrm{Fe}$ compared to MORB: (1) Fe oxidation and isotope fractionation processes were decoupled during low-T hydrothermal alteration, or (2) Fe oxidation occurred in a closed system, i.e. without $\mathrm{Fe}$ addition or loss, during the dehydration reactions related to the prograde metamorphism up to the blueschist facies $\mathrm{P}-\mathrm{T}$ conditions.

The metabasites of the Ile de Groix are interlayered with pelitic sediments, whose trace element composition is similar to the upper continental crust (UCC) or global subducting sediment (GLOSS), with high LILE and LREE contents (Bernard-Griffiths et al. 1986; Bosse et al. 2002; El Korh et al. 2013). Most metabasites have (La/Sm) $)_{P M}$ ratios typical of MORB (up to 1.5; John et al. 2010) (Fig. 5b; Table 3). Two samples with high $\delta^{56} \mathrm{Fe}$ (blueschist GR $11 \mathrm{~b}$ and greenschist GR 06a) have $(\mathrm{La} / \mathrm{Sm})_{\mathrm{PM}}$ ratios slightly higher than MORB (Fig. 4b). El Korh et al. (2013) have shown that metasomatic processes related to the early stages of subduction, i.e. a pronounced interaction with sediment-derived fluids, were responsible for LILE and, to a lesser extent, LREE enrichment in these two metabasites.

A recent study has determined $\delta^{56} \mathrm{Fe}$ values of subducting sediments from +0.05 to $+0.18 \%$ o [average: $+0.12 \pm 0.04(2 \sigma \mathrm{SD})$; Nebel et al. 2015], which are close to that of UCC $\left(\delta^{57} \mathrm{Fe}\right.$ of c. $+0.15 \%$, i.e. $\delta^{56} \mathrm{Fe}$ of c. $+0.10 \%$; Foden et al. 2015) and average MORB. However, the $\delta^{56} \mathrm{Fe}$ values of the metabasites of the Ile de Groix are generally heavier than those of subducting sediments.
Despite a good correlation between $\delta^{56} \mathrm{Fe}$ and $(\mathrm{La} / \mathrm{Sm})_{\mathrm{PM}}$ ratio, their heavy-Fe isotopic composition cannot be explained by an interaction with sediment-derived fluids, in agreement with the absence of correlation between $\delta^{56} \mathrm{Fe}$ and $\mathrm{Ba} / \mathrm{La}$ values (Electronic Appendix; Fig. A2). Only the garnet-free blueschist GR $12 \mathrm{~b}$ has a high (La/ $\mathrm{Sm})_{\mathrm{PM}}$ ratio of 3.87 and does not plot along the $(\mathrm{La} / \mathrm{Sm})_{\mathrm{PM}}$ vs. $\delta^{56} \mathrm{Fe}$ line (Fig. 5b). While intensive interaction with sediment-derived fluids has increased its light rare-earth element (LREE) content (El Korh et al. 2013), this sample only shows restricted $\mathrm{Fe}$ isotope fractionation. Despite its high $\mathrm{Fe}^{3+} / \Sigma \mathrm{Fe}$ ratio, blueschist GR $12 \mathrm{~b}$ has a $\delta^{56} \mathrm{Fe}$ value similar to rocks with a lower $\mathrm{Fe}^{3+} / \Sigma \mathrm{Fe}$ ratio. While largescale transfer of oxidised Fe from sediments to the mantle wedge is not considered as a significant oxidising process (Nebel et al. 2015), local $\mathrm{Fe}$ isotope re-equilibration between sample GR 12b and sediment-derived sulfate-rich and/or hypersaline fluids may have been responsible for the decoupling of $\delta^{56} \mathrm{Fe}$ and $\mathrm{Fe}^{3+} / \Sigma \mathrm{Fe}$.

\section{Fe isotope fractionation during subduction zone metamorphism}

The $\delta^{56} \mathrm{Fe}$ decrease from blueschists $(0.19-0.33 \%$ ) to eclogites $(0.16-0.18 \%$ ) is associated with an increase in $\mathrm{SiO}_{2}$ content (46.4-47.6\% in blueschists, 48.8-49.5\% in eclogites) and to a decrease in $\mathrm{Al}_{2} \mathrm{O}_{3}$ content (15.4$17.9 \%$ in blueschists, $13.7-15.4 \%$ in eclogites) (Tables 2 , 3; Fig. 3a, b). These chemical differences may suggest that iron isotope fractionation has occurred during devolatilisation reactions at the transition from blueschist to eclogite facies (500-600 ${ }^{\circ} \mathrm{C}$; El Korh et al. 2009). $\mathrm{Al}_{2} \mathrm{O}_{3}$ can be dissolved in $\mathrm{SiO}_{2}$-bearing $\mathrm{H}_{2} \mathrm{O}-\mathrm{NaCl}$ fluids that may accompany metasomatic processes in the crust and mantle during subduction-zone metamorphism (Manning 2004, 2006). Solubility of $\mathrm{Al}_{2} \mathrm{O}_{3}$ increases with pressure at temperatures of $700-1000{ }^{\circ} \mathrm{C}$ (Manning 2006). It is also significant in high-pressure environments under lower peak temperature conditions (c. $2.2 \mathrm{GPa}$ and $625{ }^{\circ} \mathrm{C}$; Widmer and Thompson 2001). Preferential mobility of $\mathrm{Al}_{2} \mathrm{O}_{3}$ during metamorphic reactions under eclogites-facies conditions (omphacite formed at the expense of glaucophane and epidote) may have resulted in a relative enrichment in $\mathrm{SiO}_{2}$ in eclogites compared to blueschists. However, blueschists and eclogites have only recorded small differences of 50-75 ${ }^{\circ} \mathrm{C}$ in peak metamorphic temperature conditions (see El Korh et al. 2009). It has been shown that subduction zone fluids are dilute $\mathrm{H}_{2} \mathrm{O}$-rich solutions (Manning 2004). Thus, fluids in equilibrium with the dehydrating rocks only generate restricted chemical changes. The elemental budget of the studied metabasites was relatively undisturbed from its hydrothermally altered protolith despite evidence of extensive dehydration. Slow fluid fluxes during dehydration 
reactions allowed major and trace elements to be recycled between the newly-formed metamorphic minerals (El Korh et al. 2009, 2013). Thus, the variations in $\mathrm{SiO}_{2}$ and $\mathrm{Al}_{2} \mathrm{O}_{3}$ contents with $\delta^{56} \mathrm{Fe}$ from garnet-bearing blueschists to eclogites reflect small variations in their protolith composition, as inferred from the well-defined $\mathrm{Y} / \mathrm{Nb}$ vs. $\delta^{56} \mathrm{Fe}$ correlation (Fig. 5a).

While the $\mathrm{Fe}_{2} \mathrm{O}_{3}^{\text {tot }}$ content does not show any welldefined correlation with the $\delta^{56} \mathrm{Fe}$ in blueschists and eclogites (Fig. 3c), the $\mathrm{Fe}^{3+} / \Sigma \mathrm{Fe}$ ratio appears to decrease with the $\delta^{56} \mathrm{Fe}$ from garnet-bearing blueschists $(0.49 \pm 0.09 ; 2 \sigma$ $\mathrm{SE})$ to eclogites $(0.37 \pm 0.07 ; 2 \sigma \mathrm{SE})$ (Table 3 ; Fig. $3 \mathrm{~d})$. In blueschists and eclogites, $\mathrm{Fe}$ is mainly distributed between the main metamorphic minerals: $\mathrm{Fe}^{2+}$-rich almandine garnet (FeO: $24-31 \%$ in blueschists and $25-30 \%$ in eclogites), $\mathrm{Fe}^{3+}$-rich epidote $\left(\mathrm{Fe}_{2} \mathrm{O}_{3}: 9.1-15 \%\right.$ in blueschists and $9.8-12 \%$ in eclogites), $\mathrm{Fe}^{2+}-\mathrm{Fe}^{3+}$-bearing glaucophane (FeO: $7.0-11 \%$ in blueschists and $6.2-11 \%$ in eclogites; $\mathrm{Fe}_{2} \mathrm{O}_{3}: 1.8-5.1 \%$ in blueschists and $1.9-5.1 \%$ in eclogites) and $\mathrm{Fe}^{2+}-\mathrm{Fe}^{3+}$-bearing omphacite (FeO: 3.1-7.4\%; $\mathrm{Fe}_{2} \mathrm{O}_{3}$ : 2.2-6.7\% in eclogites) (El Korh et al. 2009) (Fig. 7). Even if eclogites are characterised by the presence of $\mathrm{Fe}^{3+}$-rich omphacite formed at the expense of $\mathrm{Fe}^{2+}$-rich glaucophane, epidote in eclogites is generally richer in $\mathrm{Al}$ and poorer in $\mathrm{Fe}^{3+}$ than in blueschists $\left(\mathrm{XFe}^{3+} 0.21-0.33\right.$ in blueschists and 0.19-0.25 in eclogites) (El Korh et al. 2009). Variations in $\mathrm{Fe}^{3+} / \Sigma \mathrm{Fe}$ and $\delta^{56} \mathrm{Fe}$ are relatively restricted between bulk garnet-bearing blueschists and eclogites, suggesting that $\mathrm{Fe}$ isotope fractionation in the basic rocks was constrained by their Fe content and by their Fe redox state during metamorphic reactions (Fig. 7). While $\mathrm{Fe}^{2+}$-rich garnet has probably a light $\mathrm{Fe}$ isotopic composition (Li et al. 2016; Sossi and O'Neill 2017), a heavy-Fe isotopic composition is expected for $\mathrm{Fe}^{3+}$-richer glaucophane, omphacite and epidote, in agreement with the model of Polyakov and Mineev (2000) and with the results of Li et al. (2016) for ultra-high-pressure eclogites deriving from gabbro cumulates.

Fe solubility and transport in fluid requires chlorinity to be high (e.g. Chou and Eugster 1977). However, subduction zone fluids have generally low $\mathrm{Cl}$ concentrations that prevent $\mathrm{Fe}$ to be mobilised from the dehydrating rocks (Schneider and Eggler 1986; Mottl et al. 2004; Manning 2004). The $\mathrm{Fe}_{2} \mathrm{O}_{3}^{\text {tot }}$ compositions and $\mathrm{Fe} / \mathrm{Ti}$ ratios of metabasites do not correlate with the metamorphic facies (blueschists: 9.59-13.47\%; eclogites: 12.65-14.18\%; Fig. 3c, e). As $\mathrm{Ti}$ is relatively immobile during $\mathrm{HP}$ metamorphism, the absence of a correlation between the $\mathrm{Fe} /$ Ti ratio and the $\delta^{56} \mathrm{Fe}$ indicates that $\mathrm{Fe}$ isotopic signatures were also preserved during dehydration reactions. Fe is transported as $\mathrm{Fe}^{2+}$-chloride or $\mathrm{Fe}^{2+}$-sulphate complexes in subduction zone fluids (Manning 2004; Debret et al. 2014), which enhances light-Fe mobility. Hence, light Fe-enriched fluids would be released during dehydration reactions associated to prograde metamorphism. This leads to isotopically heavier metabasites with metamorphic grade, the inverse of what is observed (Figs. 2, 3, 4, 5).

Therefore, the distinct $\delta^{56} \mathrm{Fe}$ values of blueschists and eclogites mainly reflect variations in their hydrothermally altered protolith composition, even if small $\mathrm{Fe}$ isotope fractionation related to dehydration reactions in eclogites cannot be excluded. Only a few samples show evidence of local transport of $\mathrm{Fe}$ in high-pressure epidote segregation veins (blueschist GR 02, retrograde greenschist GR25b), which was probably enhanced by high fluid-rock ratios and by halogen complexes in the fluid phase (as suggested by the presence of F-apatite in veins) (El Korh et al. 2011), but without any significant effect on host rock $\delta^{56} \mathrm{Fe}$ values.

\section{Fe isotope fractionation during retrograde greenschist facies}

Greenschists have $\mathrm{Al}_{2} \mathrm{O}_{3}, \mathrm{SiO}_{2}$ and $\mathrm{Fe}_{2} \mathrm{O}_{3}^{\text {tot }}$ compositions and $\delta^{56} \mathrm{Fe}$ values $(+0.17$ to $+0.27 \%$ o within the range of eclogites and blueschists (Tables 2, 3; Fig. 3a-c). During the early stages of retrogression, fluid-rock interactions occurred in a closed system and garnet-bearing greenschists underwent only limited fluid-rock interactions (El Korh et al. 2013). Fluids responsible for the rehydration of the rocks were equilibrated with the metabasites (El Korh et al. 2013). Retrograde formation of Fe-rich epidote $\left(\mathrm{Fe}_{2} \mathrm{O}_{3}\right.$ 9.1-15\%), chlorite (FeO 20-23\%), barroisite ( $\mathrm{FeO} 4.3-12 \% ; \mathrm{Fe}_{2} \mathrm{O}_{3}$ 0-16\%), actinolite ( $\mathrm{FeO} 4.9-6.9 \%$; $\mathrm{Fe}_{2} \mathrm{O}_{3}$ 1.6-5.6\%) and magnetite, mainly at the expense of garnet, glaucophane and omphacite (El Korh et al. 2009), hampered any Fe loss during retrogression and, hence, any $\mathrm{Fe}$ isotope fractionation (Fig. 7). During the advanced stages of retrogression, pervasive fluid-rock interactions with upwelling fluids derived from the dehydrated metabasites were responsible for significant albitisation of the rocks (El Korh et al. 2013), and required addition of $\mathrm{CO}_{2}+\mathrm{H}_{2} \mathrm{O}$ to the fluid phase (Barrientos and Selverstone 1993). Retrograde quartz, albite and calcite veins have revealed that fluids were mainly transporting $\mathrm{Na}, \mathrm{Al}, \mathrm{Si}$ and $\mathrm{Ca}$, but were depleted in $\mathrm{Fe}$ (El Korh et al. 2011). While intensive fluid-rock interactions have strongly modified the $\mathrm{Al}_{2} \mathrm{O}_{3}$ and $\mathrm{SiO}_{2}$ compositions of albite-/calcite-bearing greenschists, their Fe content remained similar to that of high-pressure rocks and garnet-bearing greenschists, owing to the large stability field of chlorite, epidote and magnetite under decreasing P-T conditions (El Korh et al. 2009).

The $\delta^{56} \mathrm{Fe}$ values of the greenschists do not show any correlation with the $\mathrm{Fe}^{3+} / \Sigma \mathrm{Fe}$. The garnet-bearing greenschists have recorded $\mathrm{Fe}^{3+} / \Sigma \mathrm{Fe}$ ratios $(0.41 \pm 0.10$; $2 \sigma \mathrm{SE})$ and $\delta^{56} \mathrm{Fe}$ values $(+0.17$ to $+0.27 \%$ o $)$ similar to those of high-pressure rocks (Tables 2, 3; Fig. 3d). 
Fig. $7 \quad \mathrm{Fe}_{2} \mathrm{O}_{3}$ and $\mathrm{FeO}$ budgets for blueschists GR 02 (a) and GR 25a (b), eclogites GR24a (c) and GR 29 (d), and greenschist GR 25b (e). Calculation employed the relative proportion of minerals in thin section and their mean $\mathrm{Fe}_{2} \mathrm{O}_{3}$ and $\mathrm{FeO}$ composition (from El Korh 2006, unpublished data; El Korh et al. 2009), as well as the whole rock $\mathrm{Fe}_{2} \mathrm{O}_{3}$ and $\mathrm{FeO}$ composition. The following mineral modal percentages were used: GR 02: grt [13-16], ep [32-38], gln [28-32], phe [5], ttn [3], barr [4], ap [2-3], qtz [2-5], rt [1-2]; GR 25a: grt [20], ep [33], gln [33], phe [4], ttn [4-5], qtz [2-3], chl [2], rt $[<1.5]$, ap [ $<1]$; GR 24a: grt [20], ep [21], gln [28], omph [10], barr [6], phe [6], ttn [5], qtz [3], Fe ox [1]; GR 29: grt [18-20], ep [17-21], gln [30-35], omph [21], phe [3-4], rt [2-4], qtz [1-3], ap [<2]; GR 25b: grt [13-16], ep [30-32], gln [12], act/barr [11-12], chl [14-15], ab [7], ttn [1-2], rt [1-2], qtz [1-5], ap [1-2], phe [1], Fe ox (mt) [1-1.5]. The Fe-poor minerals (qtz, ap, ab, $\mathrm{rt}$ and $\mathrm{ttn}$ ) are not represented. Under- or overestimation of $\mathrm{Fe}_{2} \mathrm{O}_{3}$ and $\mathrm{FeO}$ distribution results from compositional heterogeneities in mineral phases, from uncertainties on $\mathrm{Fe}_{2} \mathrm{O}_{3}$ and $\mathrm{FeO}$ proportions (calculated using the structural formulae from microprobe analyses), and/ or from non-analysed accessory minerals. Accessory Fe oxides were included in the calculation only if they change the $\mathrm{Fe}$ budget significantly (a) Blueschist GR 02

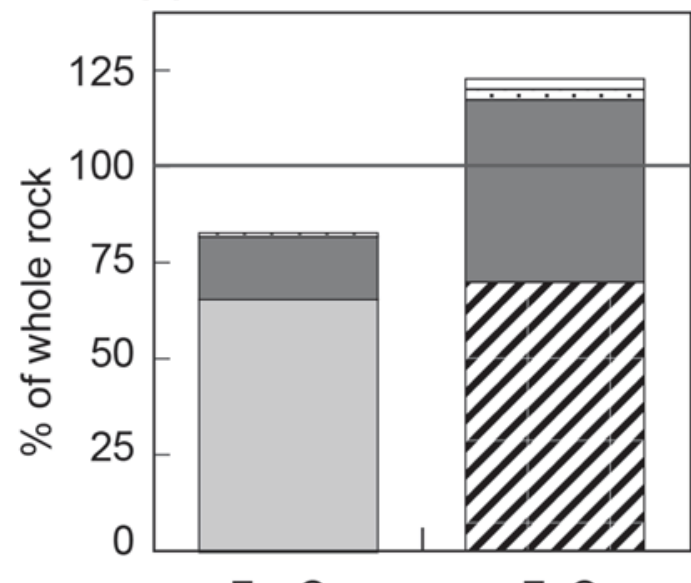

$\mathrm{Fe}_{2} \mathrm{O}_{3}$

(c) Eclogite GR 24a

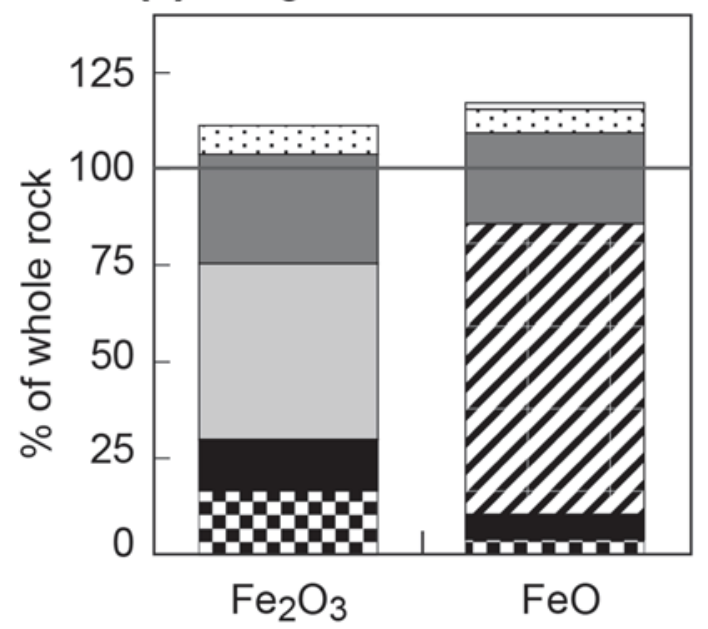

(e) Greenschist GR 25b

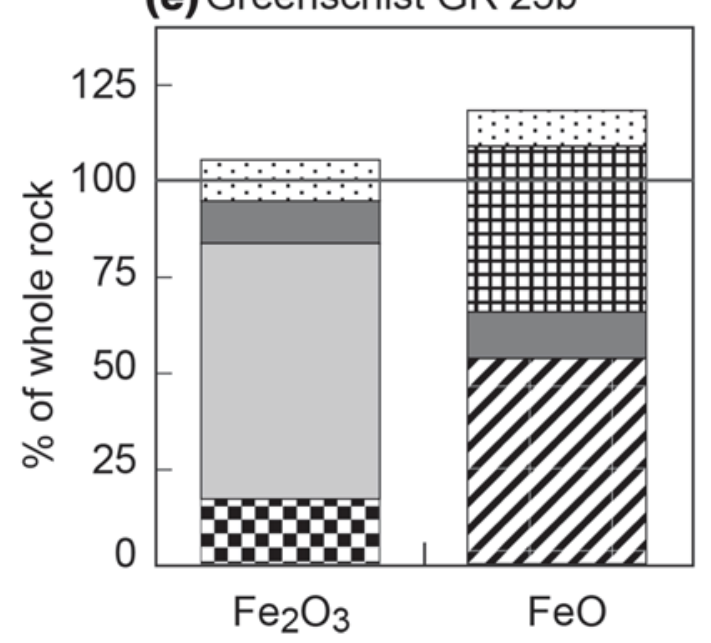

(b) Blueschist GR 25a

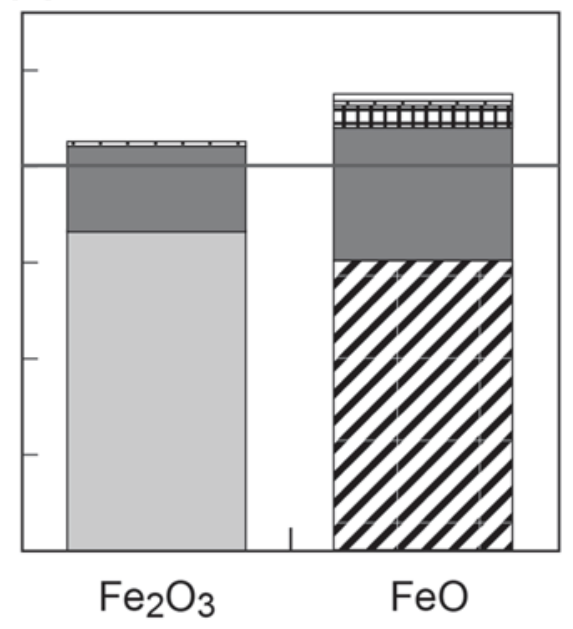

(d) Eclogite GR 29

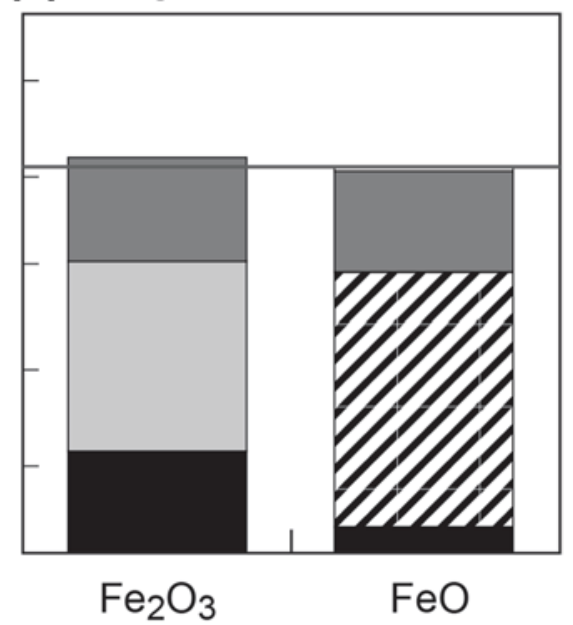

However, even if $\mathrm{Fe}$ is more reduced in the albite-/calcitebearing greenschists $\left(\mathrm{Fe}^{3+} / \Sigma \mathrm{Fe}: 0.20-0.23\right.$; Table 3), their $\delta^{56} \mathrm{Fe}(+0.20$ to $+0.23 \%$ o $)$ remains within the same range as the blueschists, eclogites and garnet-bearing greenschists.
The retrograde fluid-rock interactions have not altered Fe isotope signatures of high-pressure metabasites despite the presence of $\mathrm{CO}_{2}$ in the fluid (Barrientos and Selverstone 1993): their $\mathrm{Fe}_{2} \mathrm{O}_{3}^{\text {tot }}$ composition was preserved during 
metamorphic reactions and still limited $\mathrm{Fe}$ isotope fractionation during retrogression.

\section{Is the Fe isotope composition of the metabasites representative of the magmatic protolith?}

While pre-subduction hydrothermal alteration may have been responsible for a shift of the $\delta^{56} \mathrm{Fe}$ values by +0.06 $0.10 \%$ in the metabasites of the Ile de Groix compared to MORB, further investigations are required to determine if their heavy $\mathrm{Fe}$ isotope composition and variation up to $+0.33 \%$ could mirror an unusual heavy Fe magmatic protolith. In basaltic rocks, variations of incompatible trace element ratios [high field strength elements (HFSE) and rare-earth elements (REE)] may result from changes in mantle source composition, mixing of sources or, to a lesser extent, from fractional crystallisation (Pearce 1996; Shervais et al. 2005). Y, REE, $\mathrm{Zr}$ and $\mathrm{Nb}$ are variably incompatible elements during mantle melting and fractional crystallisation, with decreasing incompatibility behaviour from $\mathrm{Nb}$ to $\mathrm{Y}$, as well as from heavy REE (HREE) to medium REE (MREE) and light REE (LREE). This results in higher $\mathrm{Nb}$ and LREE contents in OIB formed by low degree of mantle partial melting than in MORB (e.g. Shervais et al. 2005; John et al. 2010). Variations in $\mathrm{Y} / \mathrm{Nb}, \mathrm{Zr} / \mathrm{Yb},(\mathrm{La} / \mathrm{Sm})_{\mathrm{PM}}$ and $(\mathrm{Ce} / \mathrm{Yb})_{\mathrm{PM}}$ ratios then reflect compositions that span between a depleted source [N-MORB; high $\mathrm{Y} / \mathrm{Nb}$ and $\mathrm{Zr} / \mathrm{Nb}$, and low $(\mathrm{La} / \mathrm{Sm})_{\mathrm{PM}}$ and $(\mathrm{Ce} / \mathrm{Yb})_{\mathrm{PM}}$ ratios] and an enriched source [E-MORB and OIB; low $\mathrm{Y} / \mathrm{Nb}$ and $\mathrm{Zr} / \mathrm{Nb}$, and high $(\mathrm{La} / \mathrm{Sm})_{\mathrm{PM}}$ and $(\mathrm{Ce} /$ $\mathrm{Yb})_{\mathrm{PM}}$ ratios] (e.g. Shervais et al. 2005; John et al. 2010) (Fig. 5).

The metabasites of the Ile de Groix are former tholeiitic E-MORB basalts, whose HFSE and REE compositions have evolved between enriched source and depleted source end-members (El Korh et al. 2013) (Fig. 5). Moreover, the correlation between the $\mathrm{Y} / \mathrm{Nb}$ and $\mathrm{Zr} / \mathrm{Nb}$ ratios described by El Korh et al. (2013) indicates that variations in the basaltic protolith composition cannot be considered as an effect of fractional crystallisation. The $\delta^{56} \mathrm{Fe}$ values of the studied metabasites increase as $\mathrm{Y} / \mathrm{Nb}$ and $\mathrm{Zr} / \mathrm{Nb}$ ratios decrease, i.e. with the increase of the enrichment degree of the magmatic source (Fig. 5a; Electronic Appendix, Fig. A1). While pre-HP hydrothermal processes may have increased the LREE abundances in three metabasite samples, the increase in $\delta^{56} \mathrm{Fe}$ with $(\mathrm{La} / \mathrm{Sm})_{\mathrm{PM}}$ and $(\mathrm{Ce} / \mathrm{Yb})_{\mathrm{PM}}$ ratios rather supports a magmatic origin. The more enriched samples have more variable $\mathrm{Fe}$ isotopic compositions. A similar behaviour can be observed between tholeiitic and alkaline basalts from various localities (Fig. 5a, b; Electronic Appendix, Fig. A1). Thus, variations in $\mathrm{Fe}$ isotopic compositions in the samples from the Ile de Groix may reflect variations in the initial mineral assemblage of the protolith. The $\delta^{56} \mathrm{Fe}$ values of the metabasites mirror the $\mathrm{Fe}$ isotopic characteristics of their protolith, in agreement with previous studies that showed heterogeneous and isotopically heavier $\delta^{56} \mathrm{Fe}$ signatures in the more enriched basalts (OIB) than in MORB and BABB (Weyer and Ionov 2007; Teng et al. 2013; Fig. 5a).

The $\delta^{56} \mathrm{Fe}$ values of +0.16 to $+0.33 \%$ o measured in the metabasites of the Ile de Groix are higher than the $\delta^{56} \mathrm{Fe}$ values generally measured in N-MORB $(+0.06$ to $+0.17 \%$; Weyer and Ionov 2007; Craddock and Dauphas 2011; Teng et al. 2013), E-MORB (+0.09 to $+0.17 \%$; Teng et al. 2013; Nebel et al. 2013) and BABB ( -0.01 to $+0.11 \%$; ; Teng et al. 2013; Nebel et al. 2013), as well as in OIB $(+0.05$ to $+0.30 \%$; Weyer and Ionov 2007; Teng et al. 2008, 2013; Schuessler et al. 2009; Craddock and Dauphas 2011; Konter et al. 2016), or in island arc basalts and lavas (IAB, IAL) ( -0.04 to $+0.15 \%$; Dauphas et al. 2009; Nebel et al. 2015) (Fig. 6). In addition, our results are in accordance with the unusual heavy $\delta^{56} \mathrm{Fe}$ values (up to $+0.34 \%$ o) recently determined in Samoan differentiated lavas (Konter et al. 2016) (Fig. 6), although the chemical composition of the metabasites of the Ile de Groix $\left(\mathrm{SiO}_{2}\right.$ 43.2-49.5\%; $\mathrm{MgO} 4.1-7.7 \%$; $\mathrm{Fe}_{2} \mathrm{O}_{3}^{\text {tot }}$ 9.6-14.3\%; El Korh et al. 2009, 2011, 2013) differs slightly from the Samoan lavas $\left(\mathrm{SiO}_{2} 42.3-52.3 \%\right.$; $\mathrm{MgO} 5.1-14.7 \%$; $\mathrm{Fe}_{2} \mathrm{O}_{3}^{\text {tot }} 7.1-$ 13.5\%; Konter et al. 2016). Enrichment in the heavy Fe isotopes in Samoan lavas was interpreted to be the result of a metasomatised mantle source or of a pyroxenite component in the source (Konter et al. 2016). By analogy, the heavy $\delta^{56} \mathrm{Fe}$ values measured in the metabasites of the Ile de Groix suggest that they derive from an unusual heavy-Fe enriched mantle source. Variations in incompatible trace element composition ( $\mathrm{Y} / \mathrm{Nb}, \mathrm{Zr} / \mathrm{Nb}$ ) may reflect changes in mantle source composition or a mixing of sources during the intra-continental back-arc basin magmatism recognised in the allochthonous domain of the Variscan belt (von Raumer et al. 2015).

\section{Implications for the mantle Fe isotopic composition}

Craddock et al. (2013) estimated the average $\mathrm{Fe}$ isotope composition of the terrestrial mantle to be $0.025 \pm 0.025 \%$ o (95\% CL), based on analyses of abyssal peridotites. However, large $\mathrm{Fe}$ isotope variations from -0.54 to $+0.16 \%$ o have been identified in bulk mantle xenoliths (Beard and Johnson 2004; Weyer and Ionov 2007; Zhao et al. 2010; Poitrasson et al. 2013; Su et al. 2015). In the following discussion, we will address how processes in subduction zones could induce $\mathrm{Fe}$ isotope mantle heterogeneities.

Only few studies have focused on $\mathrm{Fe}$ isotope fractionation in high-pressure metamorphic rocks. Debret et al. (2016) measured $\delta^{56} \mathrm{Fe}$ values in subducted 
serpentines (blueschist and eclogite facies) to vary from $-0.02 \pm 0.15$ to $+0.08 \pm 0.11 \%$ o $(2 \sigma \mathrm{SD})$. Beard and Johnson (2004) reported a narrow range of $\delta^{56} \mathrm{Fe}$ values for bulk subduction-related eclogites and separated minerals $[-0.06 \pm 0.03$ to $-0.02 \pm 0.06(1 \sigma \mathrm{SD})$ relative to igneous rocks; i.e. $+0.03 \pm 0.03$ to $+0.07 \pm 0.06$ relative to the IRMM-014 standard] that are similar within uncertainty to the value of bulk mantle $(+0.014 \pm 0.018$ to $+0.05 \pm 0.01 \%$ o (95\% CL); Weyer and Ionov 2007; Craddock et al. 2013; Sossi et al. 2016) and upper mantle rocks [+0.020 \pm 0.030 (95\% CL); Weyer and Ionov 2007]. Although they derive from a similar tectonic environment (a palaeo-subduction zone), the high-pressure rocks of the Ile de Groix have higher $\delta^{56} \mathrm{Fe}$ values, resulting from a combination of heavy-Fe magmatic and pre-HP metasomatic signatures (Fig. 6). Besides, our data are consistent with the highly variable Fe isotopic compositions found by Williams et al. (2009) for altered sheeted dykes and eclogite xenoliths $\left(\delta^{56} \mathrm{Fe}\right.$ from $-0.38 \pm 0.42$ to $+0.31 \pm 0.19 \%$; $2 \sigma \mathrm{SD})$.

Metasomatic processes in the ocean crust and mantle induced by dehydration and/or partial melting of subducted material are controlled by different parameters. Recent studies have shown that variations in the nature and mode of metasomatic processes result in variable effects on Fe isotope composition of mantle rocks (Weyer and Ionov 2007; Poitrasson et al. 2013). Fe solubility, transport and isotope fractionation in subduction zone fluids strongly depends on its oxidation state and relative abundance, as well as on the fluid composition (Polyakov and Mineev 2000; Manning 2004; Hill et al. 2010; Debret et al. 2014, 2016). Our results confirm that the subducted oceanic crust may be a source for mantle iron isotope heterogeneities at different depth levels:

(1) The subducted metabasites have retained the heavy $\mathrm{Fe}$ isotopic signatures of their hydrothermally altered protolith until eclogite facies $\mathrm{P}-\mathrm{T}$ conditions were reached (1.6-2.5 GPa; 500-600 $\left.{ }^{\circ} \mathrm{C} ; 60-70 \mathrm{~km}\right)$, owing to the large stability of Fe-rich minerals and restricted variations of $\mathrm{Fe}^{3+} / \Sigma \mathrm{Fe}$ in high-pressure metabasites (Fig. 8). According to Beard and Johnson (2004), fluid released during dehydration of the altered oceanic crust may serve as metasomatic agents and produced isotopically variable mantle composition through selective $\mathrm{Fe}$ transfer from the crust. Fluids were mainly equilibrated with the subducted metabasites of the Ile de Groix during dehydration reactions, as fluid-rock interactions mostly occurred at low fluid/rock ratios and slow fluid migration rates (El Korh et al. 2011, 2013). Large-scale transport of $\mathrm{Fe}$ from the basaltic crust to the mantle wedge requires $\mathrm{Cl}$ and/or $\mathrm{SO}_{\mathrm{X}}$ to be released in the fluid phase (Manning 2004; Debret et al. 2014) and

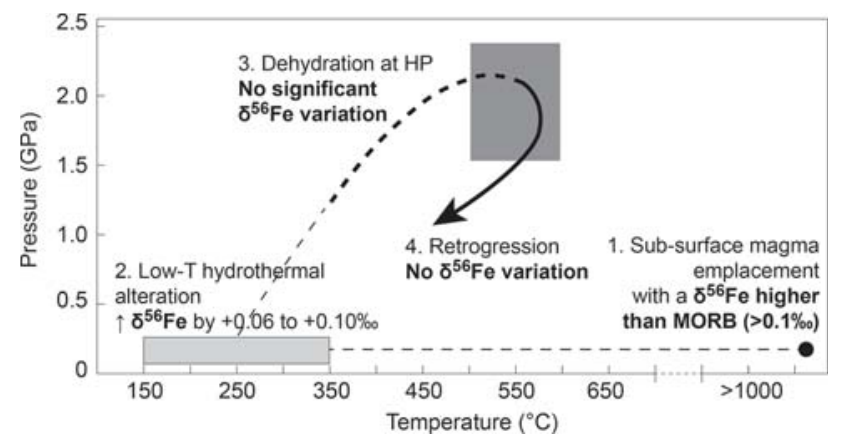

Fig. 8 Summary of Fe isotope fractionation throughout the metamorphic cycle experienced by the samples of the Ile de Groix. The schematic P-T path in bold is from El Korh et al. (2009) (dotted line prograde path; continuous line retrograde path). The dark grey field represents the maximum peak $\mathrm{P}-\mathrm{T}$ conditions calculated for eclogite GR 29. The light grey field represents the P-T conditions of low-T hydrothermal alteration. Thin dotted lines are the supposed trajectories followed by the rocks since the basaltic protolith emplacement to its embedment in the subduction zone

Fe to be mobilised during metamorphic reactions (i.e. breakdown of a Fe-rich phase). However, our results argue that metasomatism induced by metabasitederived fluids may only have a limited or a local effect on $\mathrm{Fe}$ isotope heterogeneities under subsolidus conditions, when Fe is hosted by metamorphic minerals in metabasites at the transition from blueschist to eclogite facies and thus can be relatively immobile.

(2) Subduction of the heavy-Fe oceanic basaltic crust to deeper levels can preferentially carry the isotopically heavier $\mathrm{Fe}$ in the mantle. The conservative behaviour of $\mathrm{Fe}$ in metabasites contrasts with a recent study in subducted serpentinites (Debret et al. 2016). The authors observed an increase in $\delta^{56} \mathrm{Fe}$ in serpentinites at the lizardite to antigorite transition (300-400 ${ }^{\circ} \mathrm{C}$ ). They suggest that dehydration reactions in subducted ultrabasic rocks may release light-Fe sulfate-rich and/ or hypersaline oxidised fluids along the mantle wedge (Debret et al. 2016). Therefore, serpentinites subducted at deeper levels can also carry heavy-Fe isotopes until the P-T conditions of antigorite breakdown are reached (100 to 200 km; Ulmer and Trommsdorff 1995; Rüpke et al. 2004).

(3) Our data predict that MORB-derived rocks with a large range of $\mathrm{Fe}$ isotope composition may be carried deeply into subduction zones. Addition of slab-derived heavy Fe to the light-Fe mantle wedge through partial melting of deeply subducted basic eclogites would preserve a MORB signature of $+0.1 \%$. It has been suggested that disequilibrium partial melting of the subducted oceanic crust (at depth $>100 \mathrm{~km}$; Rüpke et al. 2004) may produce iron isotope fractionation in basic eclogites (Williams et al. 2009). Melt extraction 
and percolation in the fore-arc mantle wedge is expected to trigger mantle metasomatism and, thus, to generate Fe isotopic heterogeneities in the mantle (e.g. Beard and Johnson 2004; Weyer and Ionov 2007; Su et al. 2015). Subsequent melting of the metasomatised heavy-Fe upper mantle may in turn be source of OIBs with elevated $\delta^{56} \mathrm{Fe}$ values (Konter et al. 2016), supporting a deep mantle cycle. By contrast, arc lavas display a lighter $\mathrm{Fe}$ isotopic signature than MORB (Sossi et al. 2016), reflecting extensive melt-depletion and preferential removal of $\mathrm{Fe}^{3+}$ over $\mathrm{Fe}^{2+}$ during prior melting, leaving a light $\mathrm{Fe}$ isotopic signature of the residue in the sub-arc mantle wedge (Nebel et al. 2013, 2015). These recent studies emphasise negligible influence of slab-derived fluids on the $\mathrm{Fe}$ isotopic composition of the mantle wedge. In agreement with these studies, our data argue for a conservative behaviour of $\mathrm{Fe}$ in subducted rocks, demonstrating that $\mathrm{Fe}$ isotopes are useful tracers of the protolith composition of magmatic subducted rocks and their precursor mantle source.

\section{Conclusions}

The metabasites of the Ile de Groix deriving from hydrothermally altered E-MORB, display $\delta^{56} \mathrm{Fe}$ values ranging from +0.16 to $+0.33 \%$, heavier than the values usually measured in MORB. However, their Fe isotopic compositions are consistent with the high $\delta^{56} \mathrm{Fe}$ obtained for differentiated oceanic lavas and OIBs, arguing that their basaltic protoliths derive from a heavy-Fe enriched mantle source. The correlation between the $\delta^{56} \mathrm{Fe}$ values and the $\mathrm{Y} / \mathrm{Nb}$ and $(\mathrm{La} / \mathrm{Sm})_{\mathrm{PM}}$ ratios indicates that the scattering of Fe isotopic compositions reflects variations in the initial basic protolith composition. Besides, Fe isotopes may have also fractionated during open-system hydrothermal alteration prior to subduction, simultaneously with Fe oxidation, which may have further enriched heavy $\mathrm{Fe}$ isotopes in the basic rocks by +0.06 to $0.10 \%$. Thus, heavy Fe isotopic compositions of the metabasites result from a combination of magmatic and pre-subduction metasomatic signatures. Dehydration and rehydration reactions related to the HP metamorphism have not generated significant $\mathrm{Fe}$ isotope fractionation in metabasites, owing to the large stability of Fe-rich minerals and restricted variations of $\mathrm{Fe}^{3+} / \Sigma \mathrm{Fe}$. During subduction, metasomatism related to fluids derived from the dehydration of hydrothermally altered metabasites might only have a limited effect on mantle Fe isotope composition under subsolidus conditions. However, disequilibrium partial melting of the subducted heavy-Fe oceanic crust and subsequent melt-induced metasomatism of the mantle wedge are expected to create mantle $\mathrm{Fe}$ isotope heterogeneities.

Acknowledgements This study benefited from constructive reviews of Oliver Nebel and Paolo Sossi. The editorial work of Othmar Müntener was greatly appreciated. Thanks to Stephanie Hayman for having read the English text. The research was supported by project P300P2_147749 of the Swiss National Science Foundation, and benefited from fundings from the Observatoire de la Terre et de l'Environnement en Lorraine (OTELo-CNRS) and the TelluS-SYSTER program from the Institut National des Sciences de l'Univers (INSU).

\section{References}

Audren C, Triboulet C, Chauris L, Lefort JP, Vigneresse JL, Audrain $\mathrm{J}$, Thiéblemont $\mathrm{D}$, Goyallon $\mathrm{J}$, Jégouzo $\mathrm{P}$, Guennoc $\mathrm{P}$, Augris C, Carn A (1993) Notice explicative de la feuille Ile de Groix à 1/25000, carte géologique. BRGM, Orléans

Ballèvre M, Pitra P, Bohn M (2003) Lawsonite growth in the epidote blueschists from the Ile de Groix (Armorican massif, France): a potential geobarometer. J Metamorph Geol 21:723-735

Barrientos X, Selverstone J (1993) Infiltration vs. thermal overprinting of epidote blueschists, Ile de Groix, France. Geology 21:69-72

Beard BL, Johnson CM (2004) Inter-mineral Fe isotope variations in mantle-derived rocks and implications for the Fe geochemical cycle. Geochim Cosmochim Acta 68:4727-4743

Bernard-Griffiths J, Carpenter MSN, Peucat JJ, Jahn BM (1986) Geochemical and isotopic characteristics of blueschist facies rocks from the Ile de Groix, Armorican Massif (northwest France). Lithos 19:235-253

Bezos A, Humler E (2005) The $\mathrm{Fe}^{3+} / \Sigma \mathrm{Fe}$ ratios of MORB glasses and their implications for mantle melting. Geochim Cosmochim Acta 69:711-725

Bosse V, Ballèvre M, Vidal O (2002) Ductile thrusting recorded by the garnet isograd from blueschist-facies metapelites of the Ile de Groix, Armorican Massif, France. J Petrol 43:485-510

Chou IM, Eugster HP (1977) Solubility of magnetite in supercritical chloride solutions. Am J Sci 277:1296-1314

Christie DM, Carmichael ISE, Langmuir CH (1986) Oxidation states of mid-ocean ridge basalt glasses. Earth Planet Sci Lett 79:397-411

Cottrell E, Kelley KA (2011) The oxidation state of Fe in MORB glasses and the oxygen fugacity of the upper mantle. Earth Planet Sci Lett 305:270-282

Craddock PR, Dauphas N (2011) Iron isotopic compositions of geological reference materials and chondrites. Geostand Geoanal Res 35:101-123

Craddock PR, Warren JM, Dauphas N (2013) Abyssal peridotites reveal the near-chondritic Fe isotopic composition of the Earth. Earth Planet Sci Lett 365:63-76

Dauphas N, Craddock PR, Asimow PD, Bennett VC, Nutman AP, Ohnenstetter D (2009) Iron isotopes may reveal the redox conditions of mantle melting from Archean to present. Earth Planet Sci Lett 288:255-267

Debret B, Andreani M, Muñoz M, Bolfan-Casanova N, Carlut J, Nicollet C, Schwartz S, Trcera N (2014) Evolution of Fe redox state in serpentine during subduction. Earth Planet Sci Lett 400:206-218 
Debret B, Millet MA, Pons ML, Bouilhol P, Inglis E, Williams H (2016) Isotopic evidence for iron mobility during subduction. Geology 44:215-218

Downes H (2001) Formation and modification of the shallow subcontinental lithospheric mantle: a review of geochemical evidence from ultramafic xenolith suites and tectonically emplaced ultramafic massifs of western and central Europe. J Petrol 42:233-250

El Korh A (2006) Métamorphisme HP-BT dans les métabasites de l'Ile de Groix, France: étude pétrologique et géochimique. Unpublished master thesis, University of Geneva, p 334

El Korh A, Schmidt STh, Ulianov A, Potel S (2009) Trace element partitioning in HP-LT metamorphic assemblages during subduction-related metamorphism, Ile de Groix, France: a detailed LAICPMS study. J Petrol 50:1107-1148

El Korh A, Schmidt STh, Vennemann T, Ulianov A (2011) Trace element and O-isotope composition of polyphase metamorphic veins of the Ile de Groix (Armorican Massif, France): implication for fluid flow during HP subduction and exhumation processes. In: Dobrzhinetskaya L, Faryad W, Wallis S, Cuthbert S (eds) Ultrahigh pressure metamorphism: 25 years after discovery of coesite and diamond. Elsevier, Amsterdam, pp 243-291

El Korh A, Schmidt STh, Ballèvre M, Ulianov A, Bruguier O (2012) Discovery of an albite gneiss from the Ile de Groix (Armorican Massif, France): geochemistry and LA-ICP-MS U-Pb geochronology of its Ordovician protolith. Int J Earth Sci 101:1169-1190

El Korh A, Schmidt STh, Vennemann T, Ballèvre M (2013) Trace element and isotopic fingerprints in HP-LT metamorphic rocks as a result of fluid-rock interactions (Ile de Groix, France). Gondwana Res 23:880-900

El Korh A, Luais B, Boiron MC, Deloule E, Cividini D (2017) Investigation of $\mathrm{Ge}$ and $\mathrm{Ga}$ exchange behaviour and $\mathrm{Ge}$ isotopic fractionation during subduction zone metamorphism. Chem Geol 449:165-181

Evans KA (2012) The redox budget of subduction zones. Earth Sci Rev 113:11-32

Foden J, Sossi PA, Wawryk CM (2015) Fe isotopes and the contrasting petrogenesis of A-, I- and S-type granite. Lithos 212-215:32-44

Fretzdorff S, Haase KM (2002) Geochemistry and petrology of lavas from the submarine flanks of Reunion Island (Western Indian Ocean): implications for magma genesis and the mantle source. Miner Petrol 75:153-184

Galvez ME, Beyssac O, Martinez I, Benzerara K, Chaduteau C, Malvoisin B, Malavieille J (2013) Graphite formation by carbonate reduction during subduction. Nat Geosci 6:473-477

Govindaraju K (1994) 1994 compilation of working values and sample description for 383 geostandards. Geostand Newsl 18:1-158

Gréau Y, Huang JX, Griffin WL, Renac C, Alard O, O'Reilly SY (2011) Type I eclogites from Roberts Victor kimberlites: products of extensive mantle metasomatism. Geochim Cosmochim Acta 75:6927-6954

Haase KM (2002) Geochemical constraints on magma sources and mixing processes in Easter Microplate MORB (SE Pacific): a case study of plume-ridge interaction. Chem Geol 182:335-355

Hill PS, Schauble EA, Young ED (2010) Effects of changing solution chemistry on $\mathrm{Fe}^{3+} / \mathrm{Fe}^{2+}$ isotope fractionation in aqueous $\mathrm{Fe}-\mathrm{Cl}$ solutions. Geochim Cosmochim Acta 74:6669-6689

Imai N, Terashima S, Itoh S, Ando A (1995) 1994 compilation values for GSJ reference samples, "Igneous rock series". Geochem J 29:91-95

Jackson MG, Hart SR, Koppers AAP, Staudigel H, Konter J, Blusztajn J, Kurz M, Russell JA (2007) The return of subducted continental crust in Samoan lavas. Nature 448:684-687

Jenner FE, O'Neill HSC (2012) Analysis of 60 elements in 616 ocean floor basaltic glasses. Geochem Geophys Geosyst 13:2
John T, Scherer E, Schenk V, Herms P, Halama R, Garbe-Schönberg D (2010) Subducted seamounts in an eclogite-facies ophiolite sequence: the Andean Raspas Complex, SW Ecuador. Contrib Miner Petrol 159:265-284

Kelley KA, Cottrell E (2009) Water and the oxidation state of subduction zone magmas. Science 325:605-607

Kessel R, Schmidt MW, Ulmer P, Pettke T (2005) Trace element signature of subduction-zone fluids, melts and supercritical liquids at $120-180 \mathrm{~km}$ depth. Nature $437: 724-727$

Konter JG, Pietruszka AJ, Hanan BB, Finlayson VA, Craddock PR, Jackson MG, Dauphas N (2016) Unusual $\delta^{56} \mathrm{Fe}$ values in Samoan rejuvenated lavas generated in the mantle. Earth Planet Sci Lett 450:221-232

Kretz R (1983) Symbols for rock-forming minerals. Am Miner 68:277-279

Langmuir CH, Bender JF, Bence AE, Hanson GN, Taylor SR (1977) Petrogenesis of basalts from the FAMOUS area: Mid-Atlantic Ridge. Earth Planet Sci Lett 36:133-156

Li DY, Xiao YL, Li WY, Zhu X, Williams HM, Li YL (2016) Iron isotopic systematics of UHP eclogites respond to oxidizing fluid during exhumation. J Metamorph Geol 34:987-997

Liu PP, Zhou MF, Luais B, Cividini D, Rollion-Bard C (2014) Disequilibrium iron isotopic fractionation during the high-temperature magmatic differentiation of the Baima Fe-Ti oxide-bearing mafic intrusion, SW China. Earth Planet Sci Lett 399:21-29

Malaspina N, Scambelluri M, Poli S, van Roermund HLM, Langenhorst F (2010) The oxidation state of mantle wedge majoritic garnet websterites metasomatised by C-bearing subduction fluids. Earth Planet Sci Lett 298:417-426

Manning CE (2004) The chemistry of subduction-zone fluids. Earth Planet Sci Lett 223:1-16

Manning CE (2006) Mobilizing aluminum in crustal and mantle fluids. J Geochem Explor 89:251-253

Marin-Carbonne J, Rollion-Bard C, Luais B (2011) In-situ measurements of iron isotopes by SIMS: MC-ICP-MS intercalibration and application to a magnetite crystal from the Gunflint chert. Chem Geol 285:50-61

Mottl MJ, Wheat CG, Fryer P, Gharib J, Martin JB (2004) Chemistry of springs across the Mariana forearc shows progressive devolatilization of the subducting plate. Geochim Cosmochim Acta 68:4915-4933

Nebel O, Arculus RJ, Sossi PA, Jenner FE, Whan THE (2013) Iron isotopic evidence for convective resurfacing of recycled arc-front mantle beneath back-arc basins. Geophys Res Lett 40:5849-5853

Nebel O, Sossi PA, Bénard A, Wille M, Vroon PZ, Arculus RJ (2015) Redox-variability and controls in subduction zones from an ironisotope perspective. Earth Planet Sci Lett 432:142-151

Pearce JA (1996) A user's guide to basalt discrimination diagrams. In: Wyman DA (ed) Trace element geochemistry of volcanic rocks: applications for massive sulphide exploration, vol 12. Geological Association of Canada, Short Course Notes, St. John's, Newfoundland, pp 79-113

Poitrasson F, Delpech G, Grégoire M (2013) On the iron isotope heterogeneity of lithospheric mantle xenoliths: implications for mantle metasomatism, the origin of basalts and the iron isotope composition of the Earth. Contrib Miner Petrol 165:1243-1258

Polyakov VB, Mineev SD (2000) The use of Mössbauer spectroscopy in stable isotope geochemistry. Geochim Cosmochim Acta 64:849-865

Polyakov VB, Soultanov DM (2011) New data on equilibrium iron isotope fractionation among sulfides: constraints on mechanisms of sulfide formation in hydrothermal and igneous systems. Geochim Cosmochim Acta 75:1957-1974

Rosman K, Taylor P (1998) Isotopic compositions of the elements 1997. J Phys Chem Ref Data 27:1275-1287 
Rouxel O, Dobbek N, Ludden J, Fouquet Y (2003) Iron isotope fractionation during oceanic crust alteration. Chem Geol 202:155-182

Rouxel O, Shanks WC, Bach W, Edwards KJ (2008) Integrated Feand S-isotope study of seafloor hydrothermal vents at East Pacific Rise 9-10 N. Chem Geol 252:214-227

Rüpke LH, Morgan JP, Hort M, Connolly JAD (2004) Serpentine and the subduction zone water cycle. Earth Planet Sci Lett 223:17-34

Saunier G, Pokrovski GS, Poitrasson F (2011) First experimental determination of iron isotope fractionation between hematite and aqueous solution at hydrothermal conditions. Geochim Cosmochim Acta 75:6629-6654

Scambelluri M, Müntener O, Ottolini L, Pettke TT, Vannucci R (2004) The fate of B, Cl and $\mathrm{Li}$ in the subducted oceanic mantle and in the antigorite breakdown fluids. Earth Planet Sci Lett 222:217-234

Schmidt MW, Poli S (1998) Experimentally based water budgets for dehydrating slabs and consequences for arc magma generation. Earth Planet Sci Lett 163:361-379

Schneider ME, Eggler DH (1986) Fluids in equilibrium with peridotite minerals-implications for mantle metasomatism. Geochim Cosmochim Acta 50:711-724

Schuessler JA, Schoenberg R, Sigmarsson O (2009) Iron and lithium isotope systematics of the Hekla volcano, Iceland-evidence for Fe isotope fractionation during magma differentiation. Chem Geol 258:78-91

Shervais JW, Zoglman Schuman MM, Hanna B (2005) The stonyford volcanic complex: a forearc seamount in the Northern California Coast Ranges. J Petrol 46:2091-2128

Sossi PA, O'Neill HSC (2017) The effect of bonding environment on iron isotope fractionation between minerals at high temperature. Geochim Cosmochim Acta 196:121-143

Sossi PA, Foden JD, Halverson G (2012) Redox-controlled iron isotope fractionation during magmatic differentiation. Contrib Miner Petrol 164:757-772

Sossi PA, Nebel O, Foden JD (2016) Iron isotope systematics in planetary reservoirs. Earth Planet Sci Lett 452:295-308

Su BX, Teng FZ, Hu Y, Shi RD, Zhou MF, Zhu B, Liu F, Gong XH, Huang QS, Xiao Y, Chen C, He YS (2015) Iron and magnesium isotope fractionation in oceanic lithosphere and sub-arc mantle: perspectives from ophiolites. Earth Planet Sci Lett 430:523-532
Sun SS, McDonough WF (1989) Chemical and isotopic systematics of oceanic basalts: implications for mantle composition and processes. In: Saunders AD, Norry MJ (eds) Magmatism in ocean basins, vol 42. Geological Society of London Special Publication, pp 313-345

Teng FZ, Dauphas N, Helz RT (2008) Iron isotope fractionation during magmatic differentiation in Kilauea Iki Lava Lake. Science 320:1620-1622

Teng FZ, Dauphas N, Huang S, Marty B (2013) Iron isotopic systematics of oceanic basalts. Geochim Cosmochim Acta 107:12-26

Ulmer P, Trommsdorff V (1995) Serpentine stability to mantle depths and subduction related magmatism. Science 268:858-861

von Raumer JF, Stampfli GM, Arenas R, Martínez SS (2015) Ediacaran to Cambrian oceanic rocks of the Gondwana margin and their tectonic interpretation. Int J Earth Sci 104:1107-1121

Weyer S, Ionov DA (2007) Partial melting and melt percolation in the mantle: the message from Fe isotopes. Earth Planet Sci Lett 259:119-133

Widmer T, Thompson AB (2001) Local origin of high-pressure vein material in eclogite facies rocks of the Zermatt-Saas zone, Switzerland. Am J Sci 301:627-656

Williams HM, McCammon CA, Peslier AH, Halliday AN, Teutsch N, Levasseur S, Burg JP (2004) Iron isotope fractionation and the oxygen fugacity of the mantle. Science 304:1656-1659

Williams HM, Peslier AH, McCammon C, Halliday AN, Levasseur S, Teutsch N, Burg JP (2005) Systematic iron isotope variations in mantle rocks and minerals: the effects of partial melting and oxygen fugacity. Earth Planet Sci Lett 235:435-452

Williams HM, Nielsen SG, Renac C, Griffin WL, O'Reilly SY, McCammon CA, Pearson N, Viljoen F, Alt JC, Halliday AN (2009) Fractionation of oxygen and iron isotopes by partial melting processes: implications for the interpretation of stable isotope signatures in mafic rocks. Earth Planet Sci Lett 283:156-166

Zhao XM, Zhang HF, Zhu XK, Tang SH, Tang YJ (2010) Iron isotope variations in spinel peridotite xenoliths from North China Craton: implications for mantle metasomatism. Contrib Miner Petrol 160:1-14 